\title{
Water in India's development: Issues, developmental policy and programmes, and planning approach
}

\author{
MAHESH C CHATURVEDI \\ Applied Mechanics Department, Indian Institute of Technology, New Delhi 110016, India

\begin{abstract}
The importance of water resources development for sustaining life and the agrarian economy under the conditions prevalent in India is brought out. The inadequacy of drinking water and irrigation facilities inspite of large investments under the various Plans is very disappointing, as also the poor development of the hydroelectric potential. Despite the rich environmental and natural resources of India, there has been very little developmental work due to various reasons, chief of them being non-involvement by specialized technologists in the areas where they matter most. The need for a scientific policy and a planned approach is emphasized so that higher employment generation and rapid economic growth can be achieved.
\end{abstract}

Keywords. Water resources development; developmental policy; technological planning.

\section{Introduction}

From legendary accounts down to latest planning documents, development of water resources has been considered to be of the greatest importance in India. This is understandable in view of its crucial importance for sustaining life and the agrarian economy under the characteristic climatic and hydrologic conditions of India. Yet even till the beginning of the Sixth Five Year Plan (1981) this development could not be described as satisfactory. For instance only $10 \%$ of the rural population had been supplied with safe drinking water and only about $30 \%$ of the cultivated land had been irrigated (Sixth Five Year Plan 1981). The reliability and quantity of water supplied for irrigation is also inadequate and is reflected in low yields. As stated in the Sixth Plan Document, "Inspite of the large investment made in the irrigation sector and the phenomenal growth of irrigation during the past 30 years, the returns for the investment both in terms of yield as well as finance are very disappointing". Against this achievement one may note, to give an example, the achievement of $67.7 \%$ of irrigated land in China even by 1968 and correspondingly a much more stable agricultural base (Leeden 1975; Swamy 1973).

A review of other sectors reveals a similar picture. Out of the hydroelectric potential of $75,400 \mathrm{Mw}$, only $10 \%$ had been developed and out of $40 \mathrm{MHA}$ of the flood-prone area, only 10 MHA had been provided with protection till 1981 (Sixth Five Year Plan 1981).

This sad state is particularly poignant in view of the fact that India is rich in environmental and natural resources-land, water and sunshine, as can be seen from some salient statistics given in table 1 . These are only indicative figures and have to be interpreted with care. For instance, in large parts of the world, unlike India, only one crop can be had per year, while on the other water resources may be available such that, again unlike India or China, that these could be readily used without much human 
Table 1. Some salient statistics of land, water and population

\begin{tabular}{lccc}
\hline Region & $\begin{array}{c}\text { Cultivable land/ } \\
\text { total geographical } \\
\text { area (\%) }\end{array}$ & $\begin{array}{c}\text { Utilizable } \\
\text { water/unit } \\
\text { land (m) }\end{array}$ & $\begin{array}{c}\text { Population } \\
\text { density } \\
\left(\mathbf{k m}^{2}\right)\end{array}$ \\
\hline India & 43 & 0.3 & 166 \\
China & 11 & 0.17 & 75 \\
Northwestern Europe & 26 & 0.49 & 91 \\
Southern Europe & 64 & 0.2 & 81 \\
U.S.A. & 19 & 1.4 & 22 \\
\hline
\end{tabular}

Source: Calculated from Leeden (1975) and de Mare (1977)

intervention. For instance, only $6.8 \%$ of the total cultivated area in Europe and $9.6 \%$ in USA have to be irrigated.

To a large extent, our colonial history may be said to be responsible for this sorry state of affairs. For instance, the net irrigation intensity (net irrigated area/net cultivated area) was only about $17 \%$ in 1947 at the time of Independence. Impressive technological achievements can be noted since then and the irrigation intensity has been almost doubled. Yet a critical study of the policy documents indicates that it has not been possible to break from the past heritage of colonial concepts, policies and institutional framework. An ad hoc, technologically-oriented planning and bureaucratically-managed development by officers rather than by specialised professional engineers continues. It will be argued that all this needs to be changed as otherwise it will not be possible to break the crawling agricultural growth rate of about $2.13 \%$ of the past. Besides, a serious resource depletion and environmental dilemma will also be encountered very soon. It will be shown that much higher employment generation, rapid economic growth with regional and local equity can be achieved and the spectre of resource depravation and environmental destruction can be avoided if a scientific policy and planned approach is adopted. This will require, first and foremost, institutional modernization, which is also briefly discussed.

\section{Developmental policy}

For the sake of convenience the developmental policy may be divided into two phases: (a) pre-Independence and (b) post-Independence phase. The reason for this is the scale of development and technology rather than, as will be emphasised later, modernisation of policy.

\subsection{Pre-Independence phase}

Efforts have been made in India since time immemorial, consistent with the technoeconomic capability of the people, to develop tanks, wells and small canals for the development of water resources for drinking water and irrigation. It is important to note that a considerable portion of the current water resources development is due to these historical efforts. The reliability of water supply from these historic sources was inadequate and naturally these could not lift the population out of sustenance 
agriculture or even meet the demands of the growing population triggered off in the last century.

During the early British period, little heed was paid to the development of water resources. Detailed studies of policy have not been carried out but it appears reasonable to conclude that the foreign government was primarily interested in maintaining law and order and undertaking only financially remunerative activities (Irrigation Commission 1972; Cautley 1860; Lieftink et al 1969). As Cobden stated in the British Parliament in 1855 "The single city of Manchester in the supply of its inhabitants with the single article of water has spent a larger sum of money than the East India Company has spent in the 14 years from 1834 to 1848 in public works of every kind throughout the whole of its vast dominions" (Clairmonte 1961).

The increasing population and exploitary policy of the foreign government created increasing strain on the economy and famines became more frequent and intense (Bhatia 1967). Irrigation had, therefore, to be developed to avoid politically disturbing phenomena. It is significant to note that many important irrigation works, such as the Eastern Yamuna Canal in 1820, the Eastern Yamuna and Upper Ganga Canal during 1830-1854, the Upper Bari Doab Canal in 1851, the Godavari and Krishna anicuts in 1850, the Agra Canal in 1873, to name a few, were constructed for increasing revenue and averting famines. It may be noted that irrigation activities were undertaken not where there are easily developable facilities, such as eastern Uttar Pradesh (UP) and Bihar but in the arid western and border areas. The reason was that these were more famine-prone and politically sensitive. The socio-political objective of irrigation was thus only to stabilize the sustenance agriculture for which extensive irrigation became the logical policy (Irrigation Commission 1972). Technological, economic and financial considerations also supported this policy. Groundwater control was not known at that time, the only technology known being surface diversion which cannot provide dependable and adequate water supplies. Fear of water-logging indicated extensive irrigation through diversion of the low flows. The poor paying capacity of the farmers and lack of technological capability to give assured supplies also pointed in the same direction. Similarly nonavailability of modern agricultural inputs also did not put pressure for dependable and adequate supplies.

Besides irrigation, other uses of water resources viz., navigation, flood control, drainage, hydroelectric development or even water supply for drinking purposes did not get any importance. Even irrigation got low priority compared to railways as the latter were considered essential for the maintenance of law and order. It may be noted that navigation canals were an outstanding financial investment for transport purposes in the growing economy of Europe at the beginning of the industrial revolution (Lansing 1966). The financial attraction encouraged water resources development for this purpose and even led to some private ventures in India, but it turned out to be a failure because corresponding industrial development was not taking place. Even for irrigation, the colonial government was content with supplying water up to canal outlets, leaving the rest of the task of conveyance and distribution to the farmers themselves. Activities such as land-levelling, drainage, lining of water courses etc., which demanded public participation were also not considered possible by a foreign government. These were not within the capability of the poor peasantry and were, therefore, neglected. Thus, in short, a policy of inefficient extensive irrigation through low flow diversions to stabilize the sustenance agriculture evolved from a convergence of social, political, economic, technological and financial considerations. It is significant 


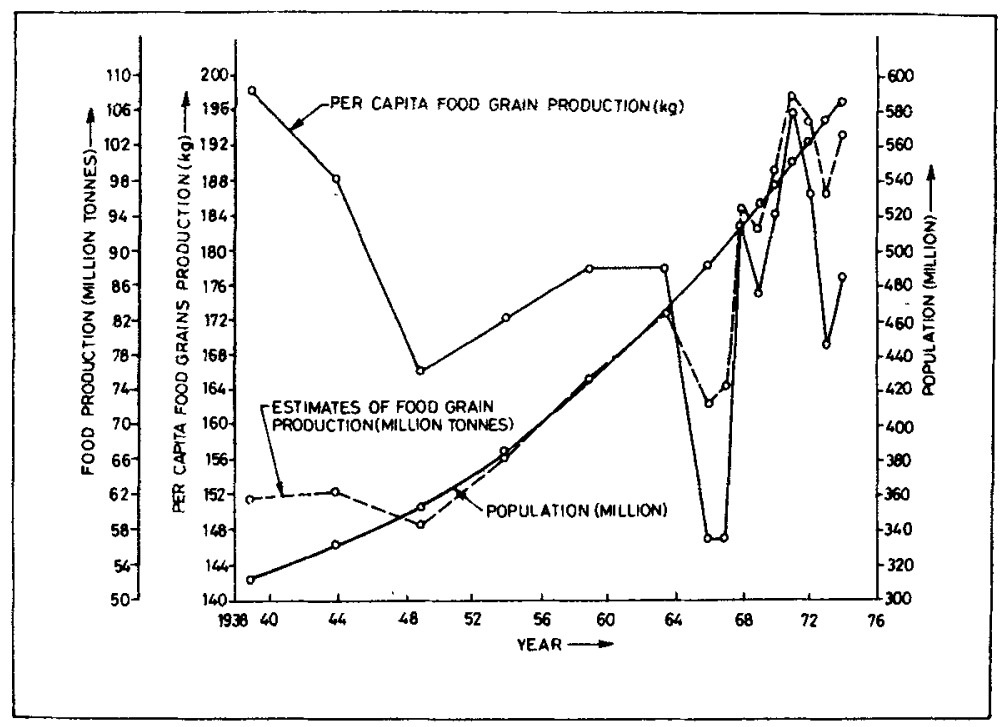

Figure 1. Population and food dilemma of India (based on data in National Agricultural Commission Report 1976)

to note that the per capita food availability continued to drop sharply till Independence, as brought out in figure 1.

\subsection{Post-Independence phase}

After Independence, although the highest priority has been laid on irrigation development and impressive developments have indeed taken place e.g. attainment of 58 MHA of irrigated area and large projects, it has continued on a technologicallyoriented ad hoc project-by-project basis without any integrated policy analysis. In fact the colonial policy of extensive irrigation has continued to be followed uncritically. Developments have also been concentrated in those areas where developments had taken place earlier without much concern for regional equity. Study of several projects, shows that even when such technologies as storage dams and groundwater development are available, the old approach of inadequate and unreliable water supplies has continued and little attention has been given to the package of associated developmental activities at the field level. A high technology bias is also distinctly evident. Ever higher dams and larger canals have been the sole preoccupation of all concerned. Projects continue to be taken up on an ad hoc basis without detailed coordinated regional planning. Completion periods of projects get extended on various grounds and irrigation adaptation follows a leisurely pace. Conceptual awareness that integrated river basin planning and conjunctive surface and groundwater development should be undertaken are often stated in Government announcements or Commission Reports, but neither are these planned nor implemented.

Of late, increasing attention has been laid on field-level developments, incorporating them with integrated rural development through command area development (CAD) and water management. The CAD proposes a systematic programme of land consolidation, scientific land-shaping, construction of water courses and field channels to carry water to individual fields, field drains development, and a system of roads which will 
enable farmers to carry the produce to the market. Besides the above measures, adequate and timely supply of inputs is proposed to be ensured and marketing and other infrastructural facilities created so that the farmers are able to derive optimum benefits from available land and water. By the end of March 1980, 76 CAD projects had been undertaken which covered an ultimate irrigation potential of $15.3 \mathrm{MHA}$ in 16 states and Union Territories. The area covered under the field channels and land levelling to the end of March 1980 was $30,82,570$ HA and 9,36,970 HA respectively. But achievements are poor and the machinery is neither adequately motivated nor appropriately educated.

Similarly soil and water conservation programmes were initiated during the First Plan period and they have progressively intensified over the successive Plan periods. Till 1979-80, an area of 23.40 MHA was treated by various soil conservation measures. Considering the magnitude of the problem of land degradation, its regional and interstate ramifications and the high national priority accorded to tackle it, the Sixth Plan aims at an additional target of 7.1 MHA on the base of 23.4 MHA. However, the same comment as for CAD applies here.

Mention may also be made of the proposed modernisation programme. It has been realised that there are a number of old irrigation projects and even those constructed recently which are not able to meet the irrigation requirements. These are planned to be modernised but details and targets have yet to be developed.

A policy analysis was attempted only by the Second Irrigation Commission in 1972. However, as a perusal of the Irrigation Commission Report (1972) or National Commission on Agriculture (1976) will indicate, it is generally an assemblage of facts or an ad hoc enunciation of some policy issues without consistency and the critical analysis needed for the scientific formulation of a water resources developmental policy. Similarly other documents of Government or senior Government policy makers give no idea of the scientific policy (Rao 1976; Murthy 1975; U N Country Paper 1977).

There is mention of a strategy consisting of (a) expeditious completion of ongoing projects, (b) action on a few selected projects to set the tempo of future development, (c) modernisation of irrigation, (d) optimisation of benefits through better operation of existing systems and conjunctive use of surface and groundwaters and adoption of warabandi and (e) efficient water management in the Sixth Plan.

The need for detailed project formulation has been noted. It is further noted that "project consultancy and design engineering organisations would need considerable strengthening in such disciplines and types of projects where such consultancy organisations do not exist ... . The requisite expertise where it is not available in the country could be drawn from amongst highly experienced and motivated Indians abroad". It is even stipulated that all project reports shall be completed in a phased manner by 1989-90.

It has been stated that "Stress is laid on dealing with interrelated problems through a system approach rather than in separate compartments, on greater management efficiency and intensive monitoring in all sections and active involvement of the people in formulating specific schemes of development at the local level and in securing their speedy and effective implementation".

Further, "The maximisation of production and income from every available litre of water will be one of the important objectives of the Plan. This will call for detailed attention to on-farm management of water jointly by the farmers in the command area of an irrigation project and the project authorities. Command area management in 
unirrigated areas and catchment area management in the catchment areas of major river systems will all have to be designed in such a manner that the people concerned and the administration can work together as partners in elevating and stabilising yields without damage to the ecosystem".

The targets, pronouncements, and strategies sound very impressive. Much has also been achieved. But when one reviews the efficiency of achievement, one is disappointed, as the Sixth Plan itself notes. The reason is not far to seek. If one examines the details of the plans and projects one finds a lack of scientific policy, detailed planning and design. Construction and management is also not efficient. There are also serious institutional and personnel deficiencies. In short, modernisation has not taken place as yet.

\section{Developmental targets and implications}

Between 1950-51 and 1978-79 the underlying trend rate of growth of national income was $3.5 \%$, of agricultural production $2.7 \%$ and of industrial production $6.1 \%$. In per capita terms, income has grown at a trend rate of $1.3 \%$, which after allowing for the rising share of investment in national income, has meant a modest $1.1 \%$ per annum rise in per capita consumption. The actual growth rates have generally been much lower than the targeted growth rate (Sixth Five Year Plan 1981).

In the Sixth Plan a growth rate of 5.2 and $5.5 \%$ in the subsequent ten year periods has been envisaged. An annual growth rate of 5.20 in the value of output during the plan and 3.75 in the subsequent decade in agriculture has been postulated.

This is planned to be achieved by a rapid and long-term growth rate of irrigation of $4.2 \%$ so that the ultimate gross irrigation potential of $113 \mathrm{MHA}$ is achieved by $2000 \mathrm{AD}$ against the 1978-79 figure of $58 \mathrm{MHA}$. It may be noted that the ultimate potential of 113 MHA was proposed to be achieved by 2025 AD by the National Agriculture Commission and the rate of achievement over the same period in the past has only been about 28 MHA in contrast to postulated additional 55 MHA. It is not spelled out as to how this dramatic doubling of the rate of achievement will take place particularly when it is noted that the past achievements have been extremely disappointing.

The aforesaid plans are based on utilizing the currently estimated utilizable potential of $105 \mathrm{MHM}$ out of which $77 \mathrm{MHM}$ shall be for irrigation. The components of development are given in figure 2 on the basis of the National Agricultural Commission (1976).

In addition, a national perspective for water resources development has also been developed for storage and interbasin transfer. It envisages the construction of 18.49 МнAм of storage capacity to enable additional utilisation of 20.96 мнАм of water for irrigating an additional $35 \mathrm{MHA}$ and generation of 40 million $\mathrm{kW}$ of hydropower capacity. The particulars are given later on the basis of the Government of India document, but these are extremely flimsy (National Perspectives 1980). The development is proposed to be completed by the turn of the century.

Several contradictions are easily noted in these targets. First, the proposed development is ad hoc and conjectural. It is not based on any scientific policy or integrated regional development techno-economic plan. There is no evidence that the inefficiently developed irrigation plan will not continue. Second, the environmental issues have not been examined. The current policy of development envisages almost total low-flow diversion. This will be totally unacceptable from environmental 


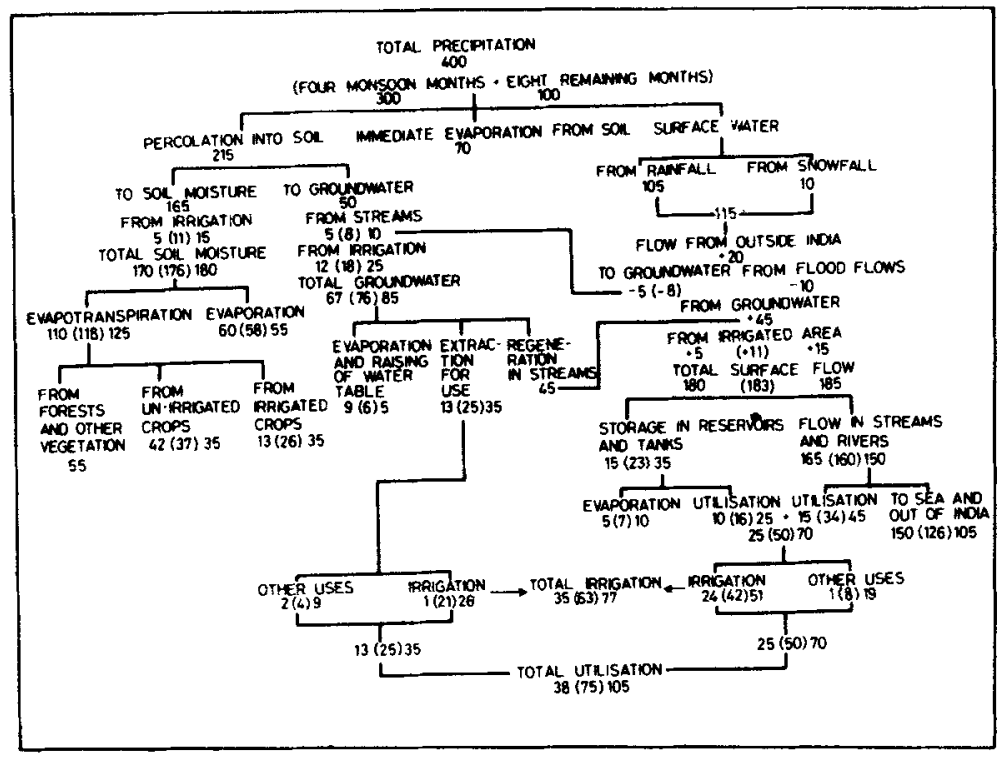

Figure 2. Approximate distribution of average annual water resources of India as in 1974 (2000 AD) and 2025 AD (MHM). Source: Natl. Agric. Comm. Rep. Vol. 5, 1976

considerations and demands for other uses (Lahiri 1975; Chaturvedi 1976). Third, the rapid rate of development contemplated is not shown in institutional modernisation, development of personnel to do the job and advance planning required to achieve these targets. The past achievement also does not inspire confidence about future targets being achieved. Fourth, although field-level developments have been mentioned, adequate emphasis has not been laid and uptill now neither plans nor institutional arrangements have been developed to achieve these targets. Fifth, groundwater development is likely to face energy constraints in view of the increasing difficulty of procuring oil and the perpetual constraints of electric energy, to mitigate which adequate emphasis on rapid hydroelectric development has not been placed.

\section{Scientific developmental policy}

The central point to be emphasized is that instead of vague concepts, an ad hoc approach and project-by-project contingency development, appropriate concepts, scientific policy, integrated regional development plans based on a systems approach and detailed projects should be developed well ahead of time. Some of these points are discussed below.

\subsection{Conceptual issues}

The first point to be noted is that technological development has to be an instrument of developmental objectives. According to the Sixth Plan (1980-85) these are visualised to be (i) a significant step-up in the rate of growth of the economy, the promotion of efficiency in the use of resources and improved productivity, (ii) strengthening the impulses of modernization for the achievement of economic and technological self- 
reliance, (iii) a progressive reduction in the incidence of poverty and unemployment, (iv) a speedy development of indigenous sources of energy with proper emphasis on conservation and efficiency in energy use, (v) improving the quality of life in general with special reference to the economically and socially handicapped population, through a minimum needs programme whose coverage is so designed as to ensure that all parts of the country attain nationally accepted standards within a prescribed period, (vi) strengthening the redistributive bias of public policies and services in favour of the poor, contributing to a reduction in inequalities of income and wealth, (vii) a progressive reduction in regional inequalities in the pace of development and in the diffusion of technological benefits, (viii) promoting policies for controlling the growth of population through voluntary acceptance of small family norms, (ix) bringing about harmony between the short and long-term goals of development by promoting the protection and improvement of the ecological and environmental assets, and $(x)$ promoting the active involvement of all sections of the people in the process of development through appropriate education, communication and institutional strategies (Sixth Five Year Plan 1981).

Water resources have to be developed in the context of these objectives. For this purpose, first, certain basic concepts of modern water resources and environmental systems planning should be followed in future, in contrast to the ad hoc approach of the past. It must be emphasised that technology in the present context of development of water resources has to be an instrument to attain these objectives, embedded in the socio-economic development and not an elitist activity visualised merely in terms of certain grand projects. Tremendous possibilities for economic development and employment generation through development of water resources exist. For instance it is well-known that the yields in Indian agriculture are extremely poor. The basic reason for this is the nonavailability of adequate and reliable water, because of which other inputs of modern agriculture cannot be used. Yield and other relevant statistics given in tables 2 and 3 bring out the immense potential for increasing production and employment if water and corresponding inputs could be made available (World Bank Operations 1972).

Table 2. Comparative yields of some important crops (1969)

\begin{tabular}{lccc}
\hline & \multicolumn{3}{c}{ Yield (kg per hectare) } \\
\cline { 2 - 4 } Country & Paddy & Wheat & Cotton \\
\hline Japan & 5,550 & - & - \\
UAR & 5,110 & - & 790 \\
USSR & - & - & 770 \\
France & - & 3,580 & - \\
USA & 4,790 & 2,060 & 490 \\
Taiwan & 3,510 & - & - \\
Thailand & 1,840 & - & - \\
Pakistan & 1,820 & 1,070 & 310 \\
India & 1,610 & 1,170 & 120 \\
\hline
\end{tabular}

Source: Chaturvedi (1976) 


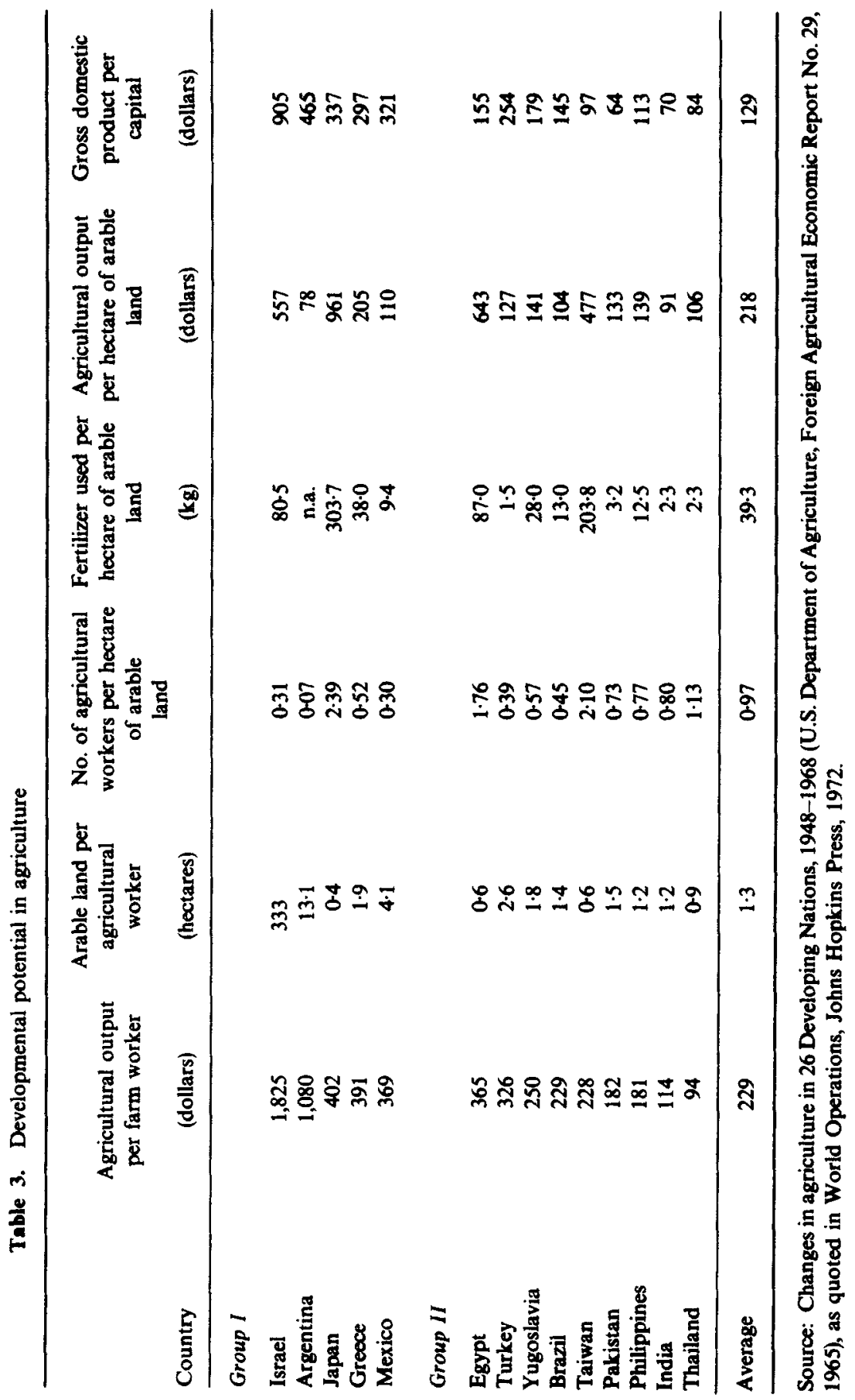


The second point to be emphasized is that water is a crucial vector of the geophysicalbiological environment and an important resource of the environmental-ecological system. Its development has thus to be in the context of socio-economic development consistent with environmental enhancement. A long-term view of the environmental state and dynamics has also to be maintained. Thus, for instance, it is necessary that certain minimum flows and water quality of surface flows is maintained, groundwater quality is constantly watched, and soil erosion is reduced.

The third point to be emphasised is the need for a creative approach. One can develop a number of technological options and one must choose critically instead of being conditioned by certain techno-economic myths. For instance there is need for conjunctive surface-groundwater and energy planning but this is more than what is meant in the Government document. Again there is need for integrating traditional technological solutions of surface diversions and conventional groundwater development with watershed development to alter land-water dynamics itself. These points are elaborated later.

In this context it may be emphasised that technology includes, besides constructed structural products, development of appropriate organisation and incentive systems. One must, therefore, think of total technological systems development. For instance when we think of dams and canals, or public or private tubewells, each has an appropriate organisation and the totality of the technological system has to be developed. One set may be better than another from the point of view of appropriateness of organisation rather than technological structure.

The fourth point to be emphasised is that water is an environmental-resource vector which has a dynamics explained through the hydrological cycle in terms of state and processes. The technological activity seeks to modify this cycle in terms of varied demands. There is thus a spatial and dynamic interlinkage of the various projects from hydrologic, economic and environmental considerations. Thus regional dynamic longterm planning is mandatory even though activity has to be initiated through individual projects.

Thus water resources development has to be undertaken in terms of individual projects developed creatively and with sensitivity in accordance with a long-term dynamic developmental policy in the context of socio-economic environmental multiobjective policies to satisfy the multipurposes. Although development has to be undertaken in terms of projects, to identify the optimum portfolio of projects longterm policy and systems planning is mandatory. Some of the policy issues with focus on various multipurposes are discussed below but it must be emphasised that the developmental policy has to consider all the purposes integrally and should be regionspecific.

\subsection{Policy issues with focus on habitat requirements}

Water supply for human settlements for drinking and other domestic purposes may be considered to be the most important demand. These requirements are a small portion of the total demand. It is considered that adequate resources and technology are available in all parts of the country to meet this demand and this could be adequately met if there is the political will.

In this context, we have also to have a policy for habitat. As tubewells and canals are developed for irrigation these can be easily used for supplying habitat demands not only of sustenance but also of environmental enhancement and recreation. 


\subsection{Policy issues with focus on irrigation}

Agricultural needs account for about $90 \%$ of resource development and are crucial for socio-economic development. Water is also important for electrical energy and navigation. Water resources development for agriculture should be integrated with energy system planning and transportation system planning for several reasons as discussed later. For developing the policy, we however concentrate on water resources development for irrigation in the first instance, but also integrate the policy with electrical energy development and flood mitigation.

The possible important technological options for multipurpose water resources development are given in figure 3. Additional programme and policies for modifying the susceptibility to flood damage and modifying the loss burden are given in figure 4.

All these options are interlinked and not necessarily exclusive i.e. they are openinteractive sets. A portfolio has to be chosen so that, consistent with conservation of resources and environmental improvement, the planning objectives generation of employment generation, economic efficiency and equity are optimally obtained temporally and spatially, taking into account the regional, hydrologic, agro-climatic and demographic potential and the developmental scenario over a period of time. The alternative configurations, scale, operating policies and timing can be identified through systems planning as discussed later. Further, as stated earlier, technological planning does not mean only optimum capacity and timing of the projects, but also

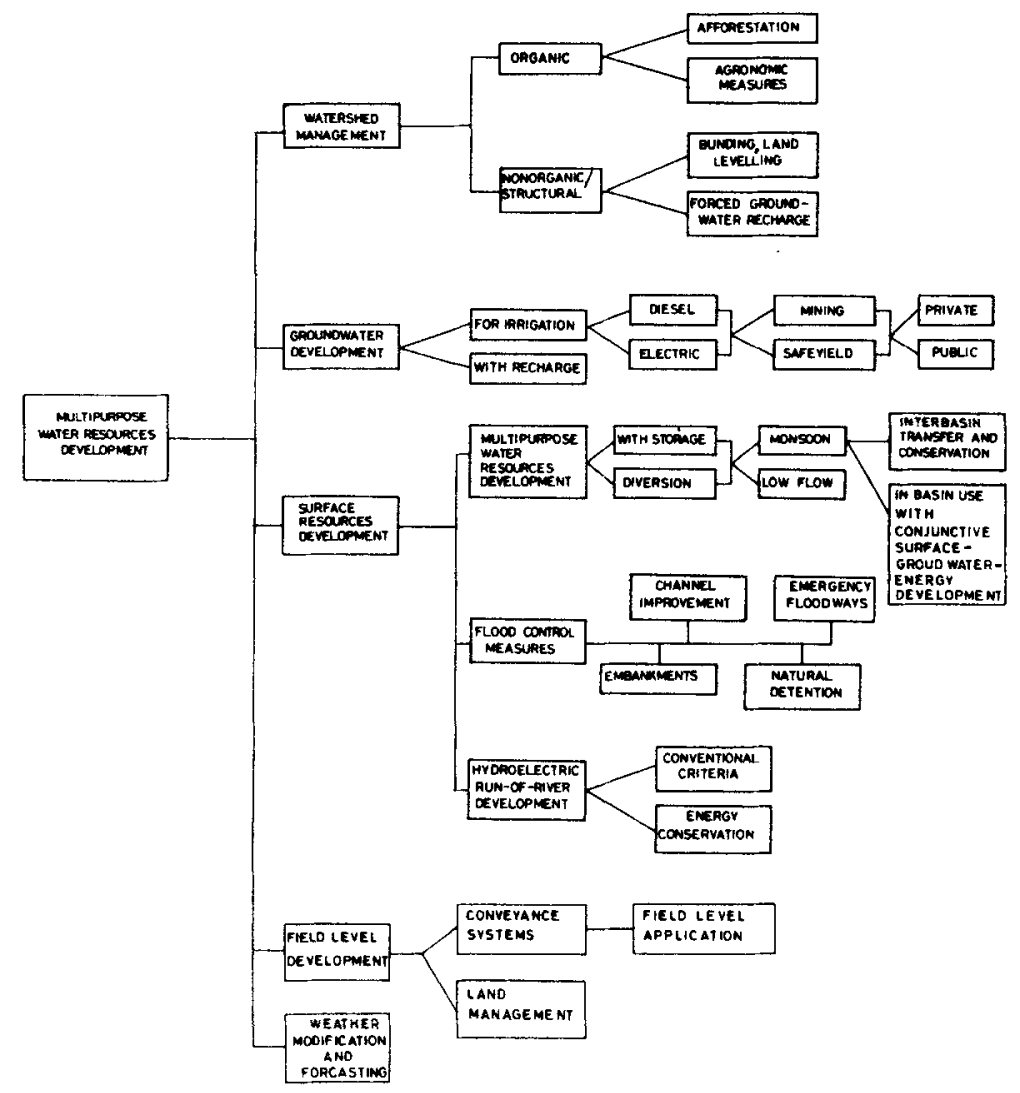

Figure 3. Technological options for water resources development 


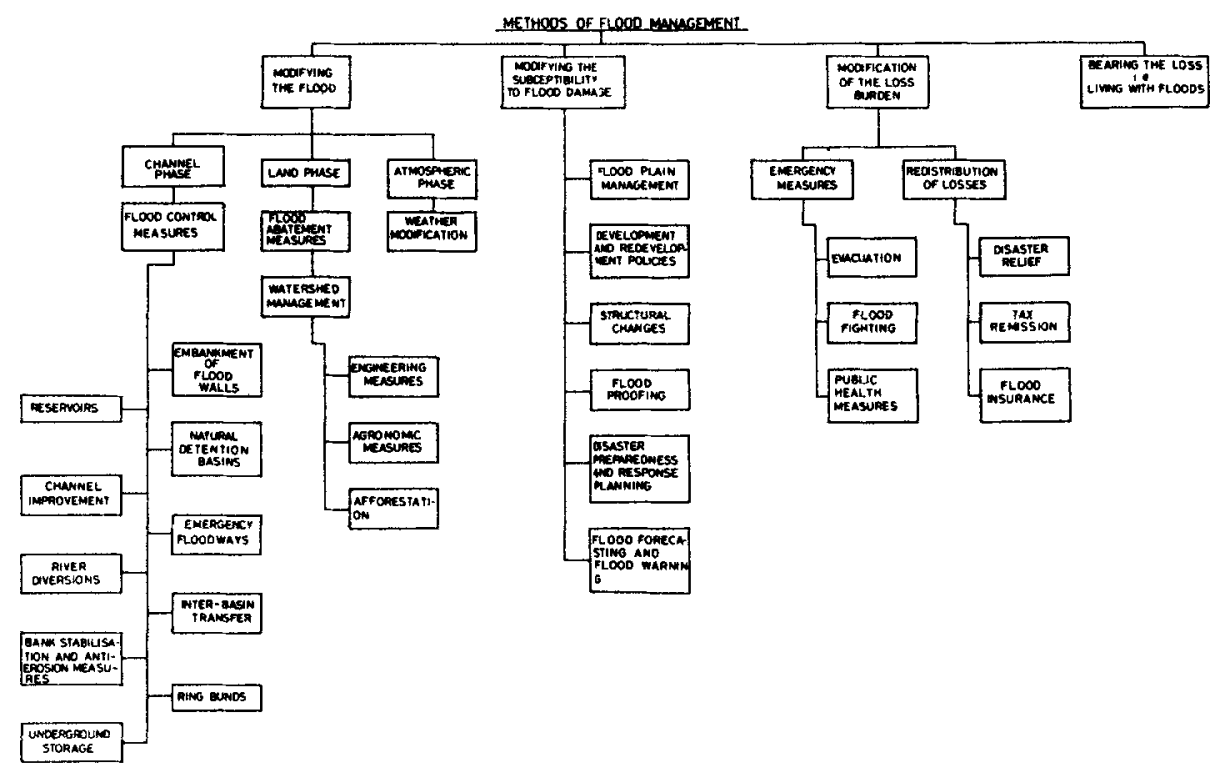

Figure 4. Programmes and policies for modifying the susceptibility to flow damage and modification of the loss burden. Source: Natl. Comm. on Floods (1980)

development of an appropriate organisation and incentive system. For instance, better economies in ground-water technological options may be obtained if cooperatives are developed at the field level. This is a difficult task requiring social management and, therefore, while it may be attempted in the long run, less efficient technology of individually-developed small-scale tubewells may be encouraged, if necessary.

Let us examine each set starting with watershed management. Traditionally, water resources developmental activities have centred around spatial and temporal transformation through structural techniques of diversion works, dams and tubewells after certain land-water interactions have taken place. It may be worth considering altering land-water dynamics through organic and non organic/structural techniques as shown in figures 3 and 4 for flood mitigation, erosion control and water resources development through additional groundwater recharge. Certain areas like the alluvial plains of the Ganga basin offer attractive opportunities (Indo-U.S. Scientists Workshop 1981). The scheme of watershed management is particularly important in conjunction with groundwater recharge as discussed later and for development of runoff from the entire land area. The issue is that the hydro-geological interaction, particularly from the resource point of view is as shown in figure 5. By technological intervention, the natural state can be altered at any level of interaction.

Groundwater development, particularly in the alluvial Indo-Gangetic plains and Eastern coastal regions is of particular importance and priority as it can be developed fast. There are several policy issues such as what should be the scale-small or large; what should be the organisation - private or public; whether it should be diesel or electric and whether there should be mining or whether development should be confined to safe yield. Each can be considered a different technology and tested through systems models. Some aspects may be noted.

Groundwater development through private low capacity pumps has the advantage of mobilising local initiative, generating fast development, employment through simple 


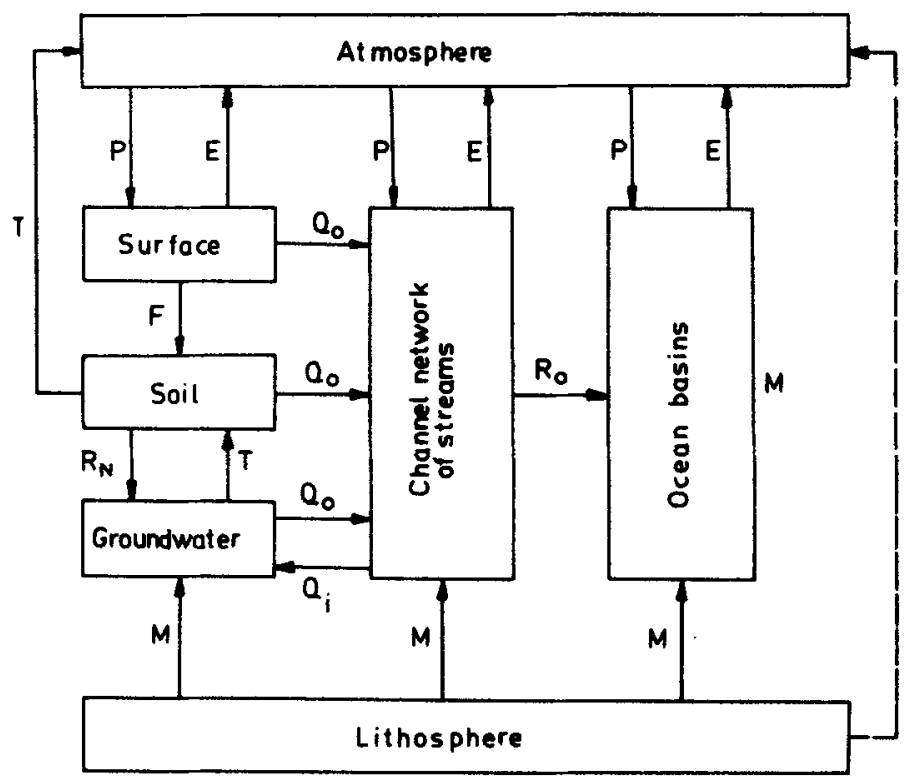

Figure 5. Hydrogeological interaction. P: precipitation, $E$ : evaporation, $T$ : transpiration, $Q_{0}$ : surface runoff, $F$ : infiltration, $Q_{i}:$ groundwater seepage, $M$ : water of volcanic origin, $R_{N}$ : percolation

construction techniques and assurance of more dependable supplies. Public tubewells provide economies of scale. It is debatable which contributes more to social justice. It can be argued that private development be through low-capacity diesel tubewells and public development be through high-capacity ones. Studies in one river basin indicate that large-scale tubewells give only $5 \%$ additional benefits while posing management problems (Chaturvedi \& Khepar 1981). These results are based only on one study and more studies are required. An optimum development has to be worked out for each planning unit (village, block, district) through a systems study.

In certain situations it may be possible to develop groundwater in conjunction with surface water by storing the latter through groundwater recharge. Three technological options have been suggested. One is storage of monsoon flows through induced groundwater recharge by heavy pumping prior to monsoons along perennial and nonperennial rivers. The scheme has been termed Ganga Water Machine (Revelle \& Herman 1972; Chaturvedi et al 1975; Revelle \& Lakshminarayan 1975; Chaturvedi 1981a). The second option is by heavy irrigation during monsoons through leaky canals with conjunctive prior groundwater development and its lowering (Chaturvedi \& Srivastava 1978). This has been termed as Kharif Channel Conjunctive Development and has been shown to be more economical than the first one. However, one or both can be used as found suitable.

The third alternative could be to pump down the excess rainfall at the field level itself and thereby have additional resources and reduce floods. The conventional tubewells could be used for this purpose through suitable provision of ordinary valves. Alternatively, a low-capacity low-head reversible pump would be required for this purpose. Preliminary studies have indicated its techno-economic feasibility (Sohoni 1976). It may be noted that for pumping down the water, no additional energy would be 
required, except may be at the start of the operations or for achieving high rates of recharge. The scheme is termed micro water machine. It may be noted that at this time considerable secondary energy would be available.

Certain constricting myths have arbitrarily been imposed by technologists and these have lead to a priori rejection of some of the basic options. For instance, groundwater development is often restricted to the so-called safe yield, equivalent to annual recharge. There is no reason why secular reserves could not be developed, of course, subject to a policy that in the long run a steady optimum level of groundwater and recharge is obtained from considerations of economic growth taking into account possible recharge from surface water resources or interbasin transfer. For instance, after surface water resources have been developed groundwater availability will be enhanced and therefore mining may be done in the first instance. There may be the problem, however, that in this process the performance of the shallow well may be affected but an appropriate policy can be developed.

Surface resources have been developed for a long time but here too several issues have been neglected. For surface development, the two basic options are diversions with and without storage. Storage projects are very attractive and mandatory from an electricity generation point of view and even more so when planned from considerations of conjunctive surface, groundwater and energy development point of view. Figure 6 clearly shows the substantial advantages in additional water and power supplies. The issue of induced groundwater has also to be added, and the problem has to be considered in the context of spatial availability of the resources and demands (Chaturvedi 1979). It may be emphasized that current storage developments do not generally consider this integrated development and, therefore, do not represent optimal development.

It is also mandatory that catchment area development such as watershed management and upstream construction work is completed before the storage works are undertaken so that sedimentation does not jeopardise their economic life.

Surface diversions being economical and quick to construct have been the first priority in water resources development so far. The benefit/cost ratio is particularly attractive if capacity is limited to low flows. From environmental considerations, unlimited low-flow diversions are, however, unacceptable. Perhaps limited low-flow diversions may be tolerated, but the needless mass-scale diversions have created an extremely precarious position. In the long run, minimum flows will have to be restored by substituting with other technological options and the issue of navigation has to be considered.

Surface diversions of monsoon flows, that are known as kharif channels, on the other hand, are extremely attractive, particularly if developed conjunctively with groundwater development, as discussed earlier. The groundwater table may be developed such that groundwater recharge during monsoons from kharif channels plus groundwater development from long-term policy considerations plus permissible low-flow diversions or release if there are storage works to meet the non-monsoon requirements are adequate to meet winter (rabi) and summer requirements. Correspondingly, the capacity of kharif channels can be finalised.

Monsoon flows can also be used, and have been used, through local lift schemes. This is attractive when the diversion canal may interfere with drainage and floods, as in the lower parts of the Ganga basin and Bangladesh. Lift schemes are, however, important for interbasin transfer and conservation, as discussed later. 


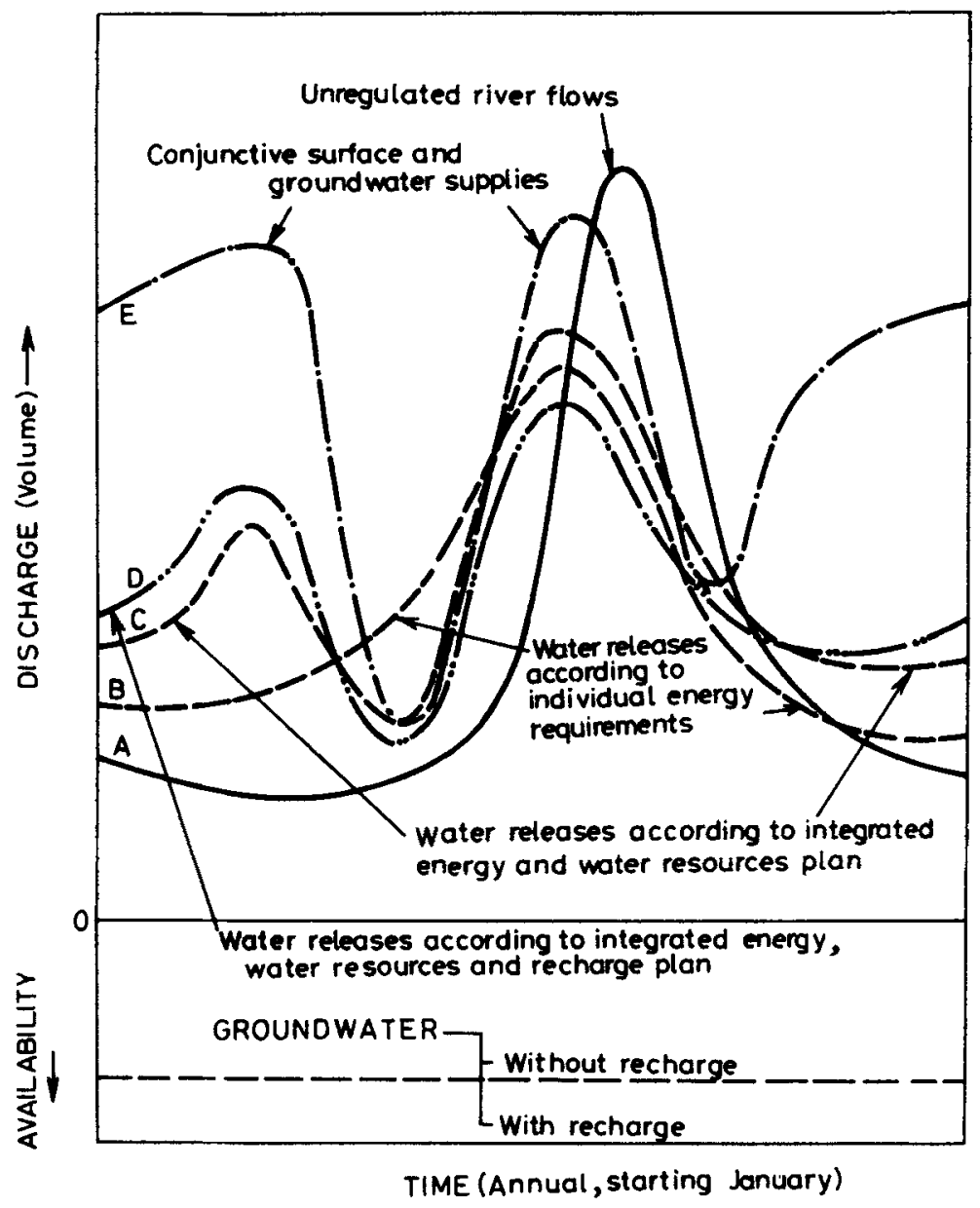

Figure 6. Conjunctive surface and groundwater development and integrated water and energy plan

The focus of attention so far has understandably been on major schemes, as they yield better benefit/cost ratio and even more important, are technologically more glamorous. It is important that total water resources development is considered integrally. It is considered that the resource availability and developmental attractiveness of the small or even non perennial schemes can be considerably improved by storing monsoon waters through appropriate technology and their development should be part of an integrated development with a portfolio of projects of appropriate capacity and with identified timing.

Besides the direct approaches of water resources development the supplies can be increased by more efficient conveyance and utilisation of water. This can be divided into two parts, the main distribution system, consisting of main canals, branches, distributaries and minors. Secondly, increased efficiency at the field level which includes increasing the efficiency of the conveyance from the main distribution system to fields and application at the field. The division has been made because the first was in the Government Sector and had received some attention but the second had. with the 
organisation of command area development activities, been left completely to the farmers till recently. Even in the first, many works are old and there is considerable scope for improvement and modernisation. The second has been termed field-level development. It is considered that it may be the most economical, easy to undertake and has large employment-generation potential. There is a choice of several alternatives, and sophisticated analysis is required to decide optimal strategies (Chaturvedi \& Khepar 1981). In view of its importance we shall refer to it again later.

\subsection{Hydroelectric development}

The hydropower potential of India is quite rich and is still largely untapped. The country's economically exploitable hydropower resources have been estimated at $75,400 \mathrm{MW}$ of which only about $10 \%$ of the potential is utilised at present (Sixth Five Year Plan 1981).

In addition, the potential of Nepal is $85,000 \mathrm{mw}$, of which almost none has been exploited. It is further considered that these estimates are on the low side and the potential is almost the double of these estimates.

At present hydroelectric development is being undertaken on an ad hoc project-byproject basis with capacity fixed on the basis of $90 \%$ availability of water resources annually with water availability estimated on a 10-day period on the basis of $90 \%$ availability. This is a gross under-utilisation of these resources for the following reasons.

First, we have to consider $90 \%$ reliability of the system and not of the individual project. Through complementarity of the different modal choices viz (i) thermal (coal and nuclear), (ii) run-of-river hydro and (iii) storage hydro, individual project capacities would be much larger through a systems approach.

Second, besides systems planning of production, integrated systems planning of supply and demand has to be considered which will lead to further optimal development of the potential. Reference has already been made to conjunctive surface groundwater and energy planning. The approach has been applied in a real-life study (Chaturvedi 1979).

With the increasing crunch on liquid energy fuel, the groundwater development tempo, which is crucial to agricultural development and consequently to national development, is in a serious state of jeopardy. Alternative sources of energy have to be developed fast and hydro-electric development has also to be accelerated.

In irrigation and hydro-projects, capacity and operation are planned on the assumption that irrigation supplies have to be met first. A nominal allocation is made, as a power cushion on an ad hoc basis. This is wrong. Alternatively optimal capacities and operation schedule have to be carefully worked out through multiobjective analysis with integrated surface-groundwater and energy planning. Often planning from energy considerations will be dominant (Chaturvedi \& Rogers 1985).

\subsection{Policy issues with focus on flood mitigation}

A unique characteristic of water resources in India is extreme temporal variation. A drought can very soon be followed by serious flood followed by a long period of water scarcity. Flood and drought are not only extreme stress characteristics for the water component of the physical environment, but for human and other biosystems as well.

A study of the flood problem has been carried out by the National Commission on 
Floods (NCF 1980) recently. It has been estimated that about 40 MHA of area may be considered as 'flood-prone' of which $10 \mathrm{MHA}$ have already been provided with reasonable protection. It is considered that $80 \%$ of the flood-prone area could be provided with reasonable protection, and that at the present level of prices, these activities will cost Rs. 51,000 crores.

Technological options for flood mitigation and programmes and policies for modifying the susceptibility to flood damage and modification of the loss burden are given in figure 4. Prevention of floods through organic activity such as afforestation and agronomic practices, appear to be important. Precipitation conservation at field level by bunding and forced groundwater recharge, storage, kharif channels and embankments, planned integrally appear to be feasible leading to flood mitigation and water resources development (Chaturvedi 1981a). The matter is not discussed further as it has to be developed in concrete terms for each river basin. We would only like to emphasize that the problem of flood management has so far been neglected in planning water resources development in India. Flood mitigation is also necessary for modernised agriculture and employment generation.

\subsection{Policy issues with focus on navigation}

Somehow navigation has been completely omitted from water resources development in India. Several reasons appear to be responsible for this omission. One, in the colonial policy, navigation was not found to be economical. Second, flow diversions for irrigation conflict with navigation requirements and apparently the latter have been summarily overlooked. Third, Indian rivers have large inter-seasonal variability and this may have posed some problems for navigation.

It appears, however, that overriding all these factors is the fact that integrated planning has not been carried out and navigation has been dropped on an ad hoc basis as water resources development is carried out on the basis of the functional orientation of planning agencies. It is not often realised that $2-3 \mathrm{~m}$ depth and $30-40 \mathrm{~m}$ width is enough for large-size navigation requirements. These dimensions would be provided even by many canals and rivers if environmental considerations were developed.

\subsection{Policy issues with focus on environment}

The natural land-water state is one level of the environment-resources vector. With development, it gets changed to another state. Any perturbation has ecologicalbiological-physical besides socio-economic implications which are extremely complex. It is difficult to say what are the minimum surface flows and groundwater development from environmental considerations but it would be logical to argue that there must be a limit to physical development and any large-scale perturbation must be carried out only after careful study of the environmental implications.

\subsection{Drought policy}

Drought is difficult to define as it relates to water availability as well as technoeconomic capability of development under a given environment. Israel is a semi desert with an annual rainfall of $500 \mathrm{~mm}$ with wide spatial and temporal variation. Yet it has the most highly modernized irrigation and agriculture development. In India according to the Irrigation Commission, $16 \%$ of the total geographical area accounting for over 
$11 \%$ of the population has been classified as drought-prone. The strategy of development would be to emphasize efficient use of local water resources supplemented by imports. Priority has to be given first to drinking and other domestic uses of water, then for industry and then for appropriate agriculture, including animal husbandry. The matter is one of detailed analysis and does not alter basic policy options.

It will follow from the above that an integrated water resources development taking into consideration all demands and resources availability on a long-term basis on a regional and interregional basis has to be carried out. The above discussion is only a background for detailed system studies as discussed later.

\section{Field level water management}

Much of the foregoing discussion was in terms of technological schemes for water resources development in the context of agricultural demands with some environmental constraints. Demand is not constant, but is a function of techno-economic capability of the users. For instance, in India, while on the one hand, water availability is inadequate, on the other hand, application is most inefficient and wasteful. It has been estimated that only $40 \%$ of water released at the canal head is made available to crops. Thus, if more efficient water management were practised, much larger areas could be irrigated or more water could be made available to the same farmers.

The technological solutions are lining of distribution systems, land levelling and adoption of appropriate water management at the field level. An integrated field-level water management can be worked out to identify optimal investment in each of these three components and to determine the shadow prices so that the relative advantage of field-level and macro-level development can be established (Chaturvedi \& Khepar 1981). We do not visualize a complete change to sprinkler system or trickle irrigation. The gravity flow system will remain the predominant technology but unit water requirements should be reduced over the course of time. In long-term planning of water resources, the urgency of the gradual improvement in efficiency has to be emphasized. Field-level development has been neglected in the past in view of certain politicalorganisational reasons. From economic, employment generation, and environmental considerations, field-level management has the highest priority.

Water management at the watershed level, which we have emphasized is, however, not a mere technological issue, but is a problem of adult education, formation of cooperatives, etc., or in short, a problem of social change as a component of integrated rural development.

\section{Interbasin transfer}

Temporal and spatial variability are usual features of water resources but the condition in India is acute. Figure 7 brings out these characteristics, suggesting the need for largescale interbasin transfer. The possibility of interbasin transfer has implications for the planning of all regional developmental projects in ensuring that important possible benefits are not pre-empted and the possibility of providing flexibility in the projects without undue extra commitment of investments is explored at the outset.

Two schemes have been proposed in this context and are worthy of examination. One is the National Water Grid proposed by Rao (1976). The other is the National 


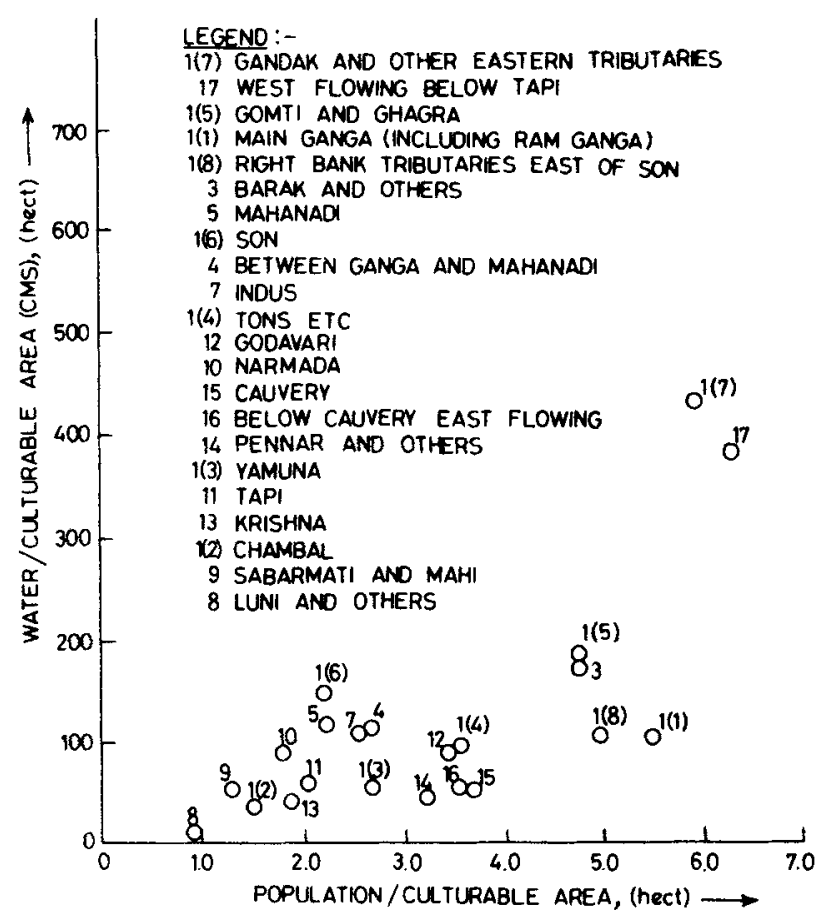

Figure 7. Basic resource relationships

Perspective for Water Resources Development developed by the Ministry of Irrigation (1980). Both are described briefly as follows.

\subsection{National water grid}

For considering interbasin transfer, Rao has considered four zones, as shown in table 4. In view of the hydrologic-physiographic conditions of the country, 17,000 cumecs of monsoon flows have been proposed to be pumped up the river Son to the river Narbada involving a lift of about $550 \mathrm{~m}$. Part of it is proposed to be used for scarcity areas in the south Ganges basin and the rest is proposed to be transferred through the Narbada to the river basins of the west flowing rivers, Sabarmati, Mahi, Narbada and Tapti, which are very deficient as shown in table 4. The east-flowing rivers of Zone 3 are proposed to be interconnected to transfer the surplus water of the North to the South. The water of the west-flowing rivers in Kerala, Zone 4 are proposed to be transferred to the scarcity areas of the east. The scheme is shown in figure 8.

\subsection{National perspective}

The National Perspective for water resources development envisaged by the Ministry of Irrigation, Government of India emphasizes development of water resources for the entire nation overriding narrow regional considerations. Essentially it seeks to increase the utilisation potential by storing the surface flows presently considered non-utilizable. The plan is based on optimum development of available storage sites, big and small, wherever feasible and interlinking of the major rivers. It is considered that 
Table 4. Zonal distribution of land-water resources

\begin{tabular}{|c|c|c|c|c|}
\hline Zone No. & $\begin{array}{c}\text { Total water } \\
\text { (annual } \\
\text { discharge } \\
\left(\times 10^{9} \mathrm{~m}^{3}\right)\end{array}$ & $\begin{array}{l}\text { Percentage of } \\
\text { land cultivated }\end{array}$ & $\begin{array}{c}\text { Water potential } \\
(\% \text { of total) }\end{array}$ & Proposed interbasin links \\
\hline $\begin{array}{l}\text { 1. Indus, Brahmaputra } \\
\text { and Ganga (North } \\
\text { Zone) }\end{array}$ & 1045 & 44 & 77 & $\begin{array}{l}\text { Brahmaputra-Ganga, } \\
\text { Ganga-Narbada }\end{array}$ \\
\hline $\begin{array}{l}\text { 2. Sabarmati, Mahi, } \\
\text { Narmada and Tapti } \\
\text { (West-flowing) }\end{array}$ & 70 & 19 & 5 & $\begin{array}{l}\text { Ganga to Narbada and } \\
\text { to others }\end{array}$ \\
\hline $\begin{array}{l}\text { 3. Subarnarekha, } \\
\text { Brahmani, Baitarni, } \\
\text { Mahanadi, } \\
\text { Godavari, } \\
\text { and Cauveri } \\
\text { (East-flowing) }\end{array}$ & 195 & 35 & 14 & $\begin{array}{l}\text { From northern rivers of } \\
\text { the region to southern } \\
\text { rivers }\end{array}$ \\
\hline $\begin{array}{l}\text { 4. West-flowing rivers in } \\
\text { kerala }\end{array}$ & 40 & 2 & 3 & $\begin{array}{l}\text { To be transferred to the } \\
\text { East }\end{array}$ \\
\hline Total & 1350 & 100 & 99 & \\
\hline
\end{tabular}

Source: Rao 1978

besides the currently estimated utilizable potential of $105 \mathrm{MHM}$, an additional $20-96$ мHM of water, an additional $35 \mathrm{MHA}$ of irrigation and $40,000 \mathrm{MW}$ hydroelectric energy, perennial inland navigation and extensive flood mitigation shall be provided.

The perspective comprises two main components viz., (i) The Himalayan rivers development; and (ii) peninsular rivers development. These are briefly outlined below.

6.2a Himalayan rivers development The Himalayan rivers development scheme envisages construction of storage reservoirs on the main Ganga and the Brahmaputra and their principal tributaries in India and Nepal along with inter-linking canal systems to transfer surplus flows of the eastern tributaries of the Ganga to the West apart from the linking of the main Brahmaputra with the Ganga. Apart from providing irrigation to an additional area of about 22 MHA and the generation of about 30 million $\mathbf{k W}$ of hydropower, it will provide substantial flood control in the Ganga-Brahmaputra basin. It would provide 1332 cumecs $(40,000$ cusecs) to Calcutta Port and would provide navigation facilities across the country. The scheme will benefit not only the States in the Ganga-Brahmaputra Basin, but also our neighbours - Nepal and Bangladesh-as well as the northern and western states in our country. Implementation of this scheme will however largely depend on the cooperation of neighbouring countries.

6.2b Peninsular rivers development Amongst the peninsular rivers, the Mahanadi and the Godavari are likely to have sizeable surpluses. It is, therefore, possible to divert the surplus of the Mahanadi and the Godavari to the water-short rivers viz., the Krishna, the Pennar and the Cauvery. The Mahanadi will also be linked on the north with BuraBalang, and 7.4 MHM of Mahanadi waters will be utilised for irrigating the coastal areas in Orissa and interlinking the rivers to even out the hydrological variations. 


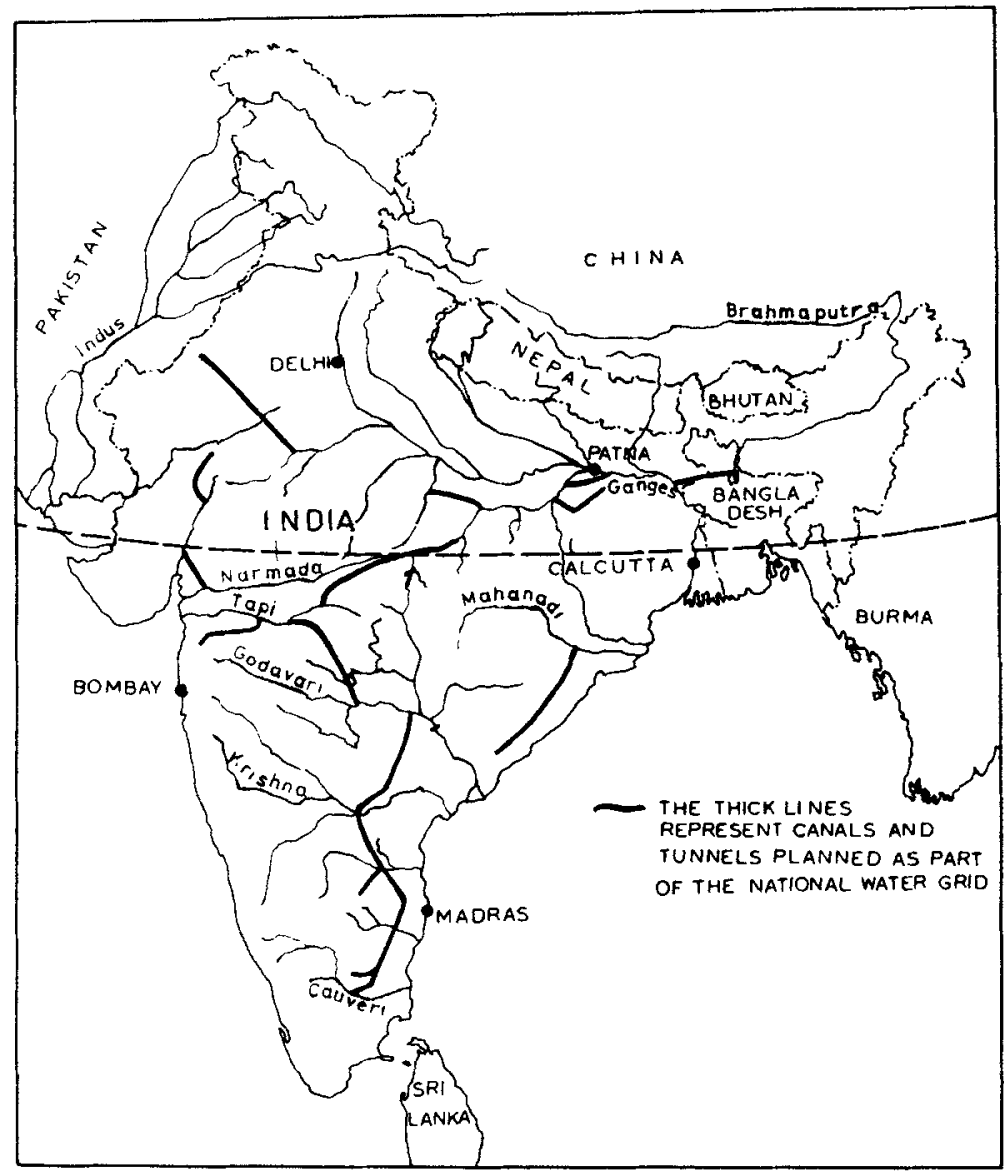

Figure 8. The drainage network in India and Bangladesh and national water grid (from Rao 1976)

Essentially this proposal contemplates diversion of $1.85 \mathrm{MHM}$ of Mahanadi flow to the Godavari and a transfer of 3.70 MHM from the Godavari and its tributaries to the Krishna Basin. This would mean a net diversion of only 1.85 мHM from the Godavari to the Krishna.

The link from the Mahanadi to the Godavari will be along the East Coast and would not involve any lift. The links between the Godavari and the Krishna will be from Polavaram to Vijayawada, Inchampalli to Pulichintala, Inchampalli to Nagarjunasagar and Wainganga to Srisailam. The last two links would involve lifts of the order of $109 \mathrm{~m}$ and $122 \mathrm{~m}$ respectively.

6.2c Interlinking Ken with Chambal The Ken, Dhasan, Betwa, Sindh and Chambal rivers are southern tributaries of the Yamuna. There is a proposal to construct dams on these and store waters optimally by interbasin interlinkages.

6.2d Division of west-flowing rivers Similarly, there is a proposal to construct a contour channel on the western ghats and provide storage wherever possible.

It is important to note that both the above proposals are conceptual and much study is required before the concepts can be finalised and the feasibility of these projects 
determined. There are many other possibilities and optimal schemes have to be worked out. Furthermore, these are not necessarily contradictory and an optimal scheme may have elements of both or several others.

Some improvements are as follows. Rao's scheme is complemented and improved by visualising both mass and energy conservation and transfer as proposed by Chaturvedi (1973). Consider the interlinkage of Zones I and II, which is crucial. The surplus water flowing down the Himalayas which is proposed to be transferred is also capable of producing energy in the Himalayas which at present is not planned to be utilised beyond $90-95 \%$ assured supplies round the year. Thus, much of the monsoon flows and possible secondary energy is wasted. Since the marginal cost of extra energy generation in the Himalayan run-of-river scheme is small, the installed capacity of these developments should be planned from a consideration of the production of this secondary energy also. This can be stored and transferred by pumping the Ganga water and storing it in the Narbada, which has tremendous and economical storage potential. This can be later released as firm energy which is almost three times more valuable than the secondary energy and particularly as peak energy which is further almost three times more valuable.

The National Water Perspective has also to be related to detailed basin planning and preceded by it. The results of a study of integrated agricultural development in the light of the current and ultimate potential without taking into account interbasin water transfer but taking into account the variable cost of surface and groundwater development in river basins is given in table. 5 . The variation in shadow price of water in

Table 5. Costs of surface water and ground water in various basins (1976-77) (Rupees/hectare meter)

\begin{tabular}{|c|c|c|c|c|c|c|}
\hline \multirow[b]{2}{*}{ River basins } & \multicolumn{3}{|c|}{ Surface water } & \multicolumn{3}{|c|}{ Ground water } \\
\hline & $\begin{array}{l}\text { Develop- } \\
\text { ment } \\
\text { cost }\end{array}$ & $\begin{array}{l}\text { Operation } \\
\text { and mainten- } \\
\text { ance cost }\end{array}$ & Total & $\begin{array}{c}\text { Develop- } \\
\text { ment } \\
\text { cost }\end{array}$ & $\begin{array}{l}\text { Operation } \\
\text { and mainten- } \\
\text { ance cost }\end{array}$ & Total \\
\hline Basin 1 & 183 & 121 & 304 & 189 & 435 & 624 \\
\hline Basin 2 & 318 & 180 & 498 & 429 & 645 & 1074 \\
\hline Basin 3 & 289 & 235 & 524 & 333 & 668 & 1001 \\
\hline Basin 4 & 136 & 85 & 221 & 316 & 835 & 1151 \\
\hline Basin 5 & 117 & 50 & 167 & 186 & 379 & 565 \\
\hline Basin 6 & 177 & 126 & 303 & 250 & 467 & 717 \\
\hline Basin 7 & 353 & 185 & 538 & 320 & 115 & 1435 \\
\hline Basin 8 & 154 & 99 & 253 & 424 & 785 & 1209 \\
\hline Basin 9 & 563 & 264 & 827 & 387 & 671 & 1058 \\
\hline Basin 10 & 156 & 96 & 252 & 241 & 690 & 931 \\
\hline Basin 11 & 1166 & 517 & 1683 & 397 & 2015 & 2412 \\
\hline Basin 12 & 220 & 91 & 311 & 361 & 893 & 1254 \\
\hline Basin 13 & 134 & 66 & 200 & 404 & 700 & 1104 \\
\hline Basin 14 & 166 & 77 & 243 & 199 & 1164 & 1363 \\
\hline Basin 15 & 370 & 160 & 530 & 269 & 1224 & 1493 \\
\hline Basin 16 & 269 & 119 & 388 & 339 & 892 & 1231 \\
\hline Basin 17 & 744 & 313 & 1057 & 364 & 1229 & 1593 \\
\hline Basin 18 & 814 & 322 & 1136 & 421 & 1065 & 1486 \\
\hline Basin 19 & 1374 & 503 & 1877 & 416 & 896 & 1312 \\
\hline Basin 20 & 396 & 170 & 566 & 238 & 1670 & 1908 \\
\hline
\end{tabular}




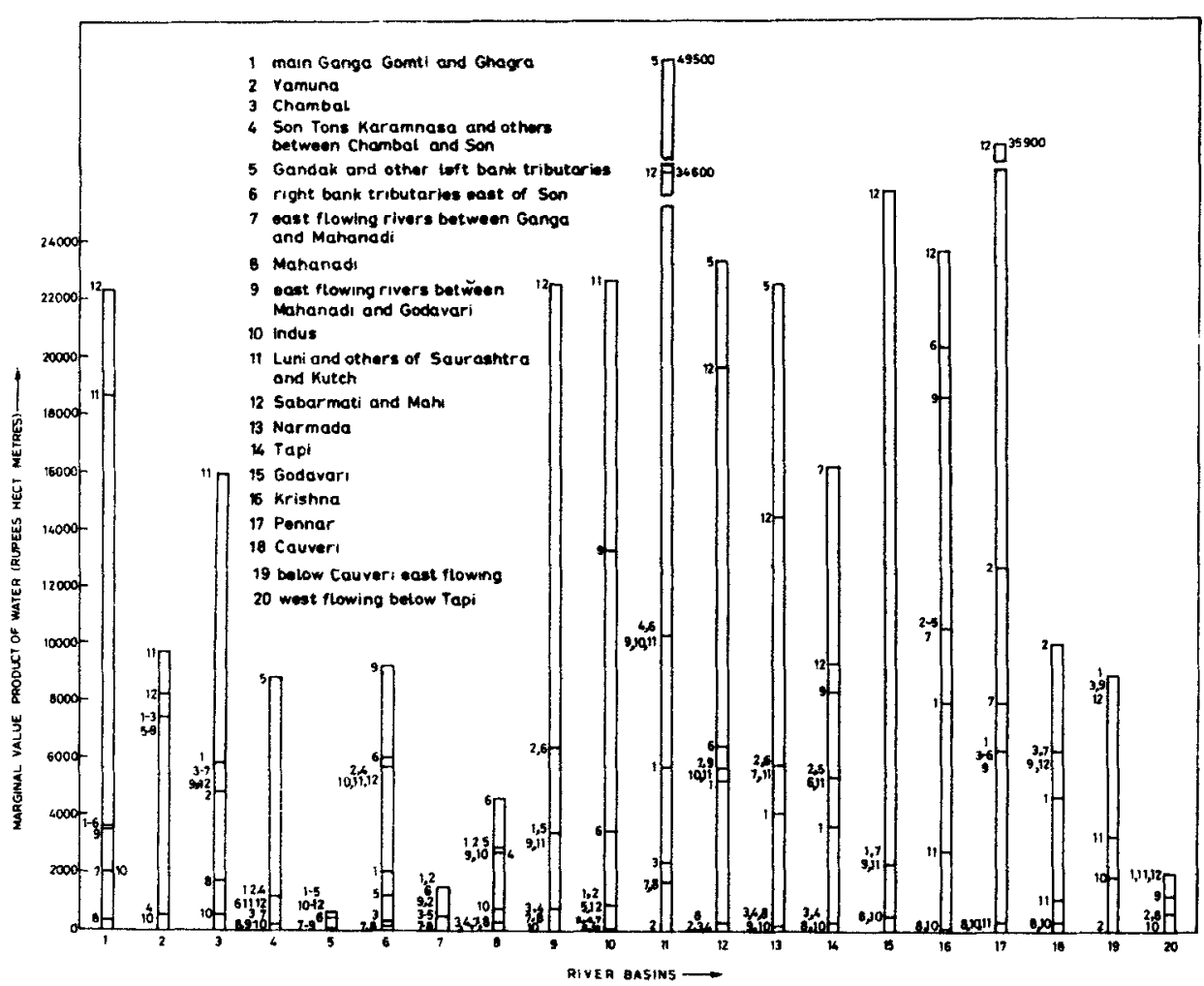

Figure 9. Marginal value product of water in different sub-basins of India in various months. Note: (1) Policy option is individual basin optimal plan at developed level of water resources with unrestricted command area and crop group area constraint. (2) Numbers refer to months starting from January. Source: Singh (1980)

different months in different basins at the stage of full utilization is shown in figure 9 (Singh 1980). Several alternative agricultural policies were studied. The water utilization and shadow prices were considerably different. The total utilization of water and fertilizer and net return are also shown in figure 10. The central point is that interbasin transfer in terms of appropriate technological configuration, capacities and timing can only be developed through a systems approach taking into account technoeconomic interlinkages with detailed regional and national planning.

\section{International issues}

Before discussing the systems planning approach the international issues involved in India's water development may be briefly reviewed. On the west, the Indus basin waters have already been agreed to be divided with Pakistan. Of the total of 21.3 million hectare-meters, India has obtained approximately $20 \%$ of the flows.

On the east a dispute exists about the minimum flows of Ganga at the IndiaBangladesh boundary - the Farakka Barrage. The Ganga and its numerous tributaries also flow through Nepal. In order to arrive at an appropriate policy, the scientific approach would be the development of a policy in totality and in isolation for each country and then through scientific analysis we can arrive at a bargained optimal policy. 


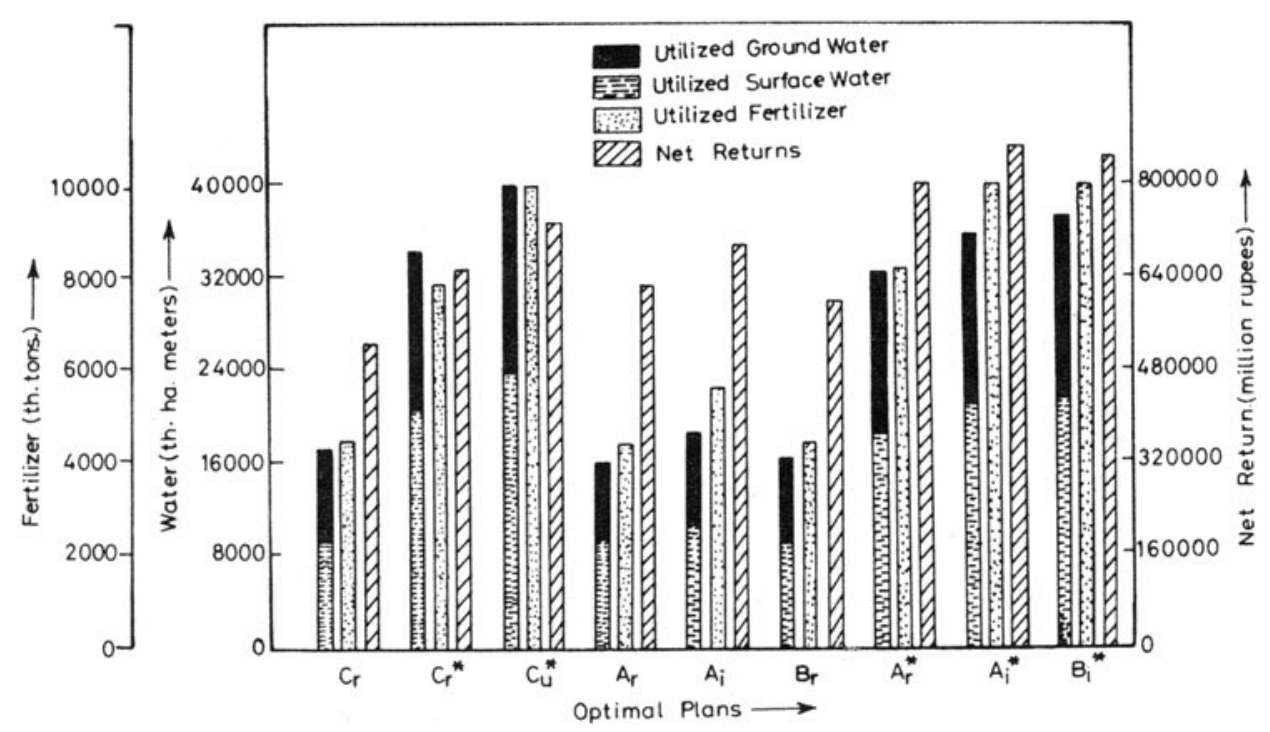

Figure 10. Utilisation of water and fertilizer and net returns under various optimal plans for the country as a whole (Source: Singh 1980)

Bangladesh and part of West Bengal constitute the largest delta of the world. Out of the total area of $204,000 \mathrm{sq} . \mathrm{km}$ of Bangladesh, 85,000 is in the delta. The average annual discharge from the Ganga, Brahmaputra and Meghana of 18.69, 19.82 and 5.10 thousand cumecs with a total of 43.61 thousand cumecs is second only to the Amazon (Leeden 1975). These carry the world's highest sediment load, with $1451 \times 10^{6}$ and 726 $\times 10^{6}$ metric tons in the Ganga and the Brahmaputra respectively. To give a quantitative idea, the estimated $2177 \times 10^{6}$ metric tonnes of average annual suspended load in the Ganga and the Brahmaputra is larger than that in the dreaded Yellow river, almost four times greater than the next highest sediment laden river Yangtze and twenty times the silt load of Nile (Leeden 1975). The flows are extremely variable over time. The Ganga draining an area of $1,098,600 \mathrm{sq}$. $\mathrm{km}$ above Goalundo has an average annual flow of 11468.3 cumecs $(405,000 \mathrm{cfs})$ with a maximum and a minimum of 70933.6 and 1161 cumecs $(2,505,000$ and $41,000 \mathrm{cfs})$. The Brahmaputra draining an area of $580,000 \mathrm{sq} . \mathrm{km}$ above Goalundo (including catchment areas outside India and Bangladesh) has an average annual flow of 19340.4 cumecs $(680,000 \mathrm{cfs})$ with a maximum and minimum of 71330 and 3115 cumecs $(2,519,000$ and $110,000 \mathrm{cfs})$. The Brahmaputra flows are much more uniform and the high flows start in May while in the Ganga they start in July.

The Ganga and the Brahmaputra unite at Aricha, the combined flow being known as the Padma river. The drainage area of the Padma between Goalundo and its confluence with Meghana is $12960 \mathrm{sq} . \mathrm{km}$ most of which is flooded during the high-flow season. The maximum observed flow of the Padma at Goalundo is 91180 cumecs.

The Meghana river, with a catchment of $80200 \mathrm{sq}$. $\mathrm{km}$ constitutes one of the highest rainfall areas of the world. It joins the Padma at Chandpur dumping another 5,100 cumecs into this tremendous water mass. The numerous channels in the delta have developed the configuration in the context of the geophysical-hydraulic characteristics of the land water mass. 
The control of these three major rivers from the Bangladesh point of view, draining an area of $1,733,200$ sq. $\mathrm{km}$ only $7.5 \%$ of which lies inside Bangladesh, poses a unique hydraulic problem which can be considered in terms of four closely interacting components; (i) high-flow (flooding) problem, (ii) river instability problem, (iii) low flow problem and (iv) the problem of the sea: tides, cyclones and salinity intrusion. In this context, water resources have to be carried for the multipurposes in view of the multiobjectives.

In developing a solution for this region, geophysical-environmental considerations have an overriding consideration in the choice of technology. Efforts should be aimed at improving the drainage and also, not to interfere with the surface drainage by construction of storage works and canals. Plentiful groundwater availability indicates that priority be given to drainage and groundwater development. Flood mitigation is an important consideration and watershed management with forced groundwater recharge as well as induced groundwater recharge appears to be indicated. It is unfortunate that while the solution may be somewhat on the lines of the Rhine Delta, practices from the arid areas of the Punjab and Western Uttar Pradesh in India are being adopted.

As the configuration is, the Brahmaputra waters are available from the hydraulic, silt and salinity intrusion point of view only for the eastern portion of Bangladesh. Therefore, in view of the geophysical and hydraulic characteristics and to control the land-water system, the Brahmaputra waters should be made more manouverable. It would thus be reasonable that the Brahmaputra is diverted to meet the Ganga upstream of the present confluence, with as high a discharge as economically possible. Since the Brahmaputra has little irrigation potential and the Ganga will have to be developed to meet the irrigation requirements of its long catchment upstream in India, the Brahmaputra link with as high a discharge as economically possible is definitely indicated from the total as well as Bangladesh's point of view. The location should be upstream so that a proper hydraulic geomorphological configuration is developed. There is no doubt the problem of fouling with drainage of the northern rivers and land use in densely populated regions but these are matters for detailed techno-economic studies.

The water management strategy will also require that first the aforesaid hydraulic management is obtained after which structured solutions may be defined. In conjunction with these structured solutions, the watershed management in the upstream area which is the major source of floods and sediment has to be taken up principally through afforestation in Nepal. The various schemes of groundwater recharge of monsoon flows in India would confer direct benefits to Bangladesh.

Regarding irrigation development, as stated earlier, the policy of groundwater pumpage through the micro water machine rather than low-flow diversion appears to be the preferred strategy particularly in view of abundant groundwater supplies, environmental considerations, and drainage/flood management. As far as the policy for India is concerned it appears that the minimum flows at Farakka should be diverted from the considerations of the land-water system in the west.

The matter requires detailed engineering-economic-systems analysis, but as a policy of development it appears that this is a unique case where optimal integrated development from environmental-economic considerations is much superior as compared to the optimal independent development. But it should not hold up any 
upstream developments as the case is more of excess of water than shortage of water in Bangladesh.

Unfortunately, in the dispute with Bangladesh the issue of the development of the water resources of Nepal has been neglected. Nepal has very rich water resources development potential and for India, development in Nepal is of utmost importance. These should be taken up integrally with the development in India and with the highest priority. It is interesting and important to note that from hydroelectric considerations there is a remarkable analogy between the potential development of Sweden and Nepal. Unfortunately while almost $60 \%$ of the potential of $25 \mathrm{MkW}$ has been developed in the former, not even $1 \%$ of the potential of $85 \mathrm{MkW}$ has been developed in the latter.

\section{Technological policy}

We have discussed some issues of developmental policy and technological strategies for water resources development in the foregoing. A package of technologies with some indication of the pros and cons subject to detailed determination of production function was indicated. Their selection, capacity, location and scheduling has to be determined from detailed systems planning for which an approach is indicated in terms of local, regional and national planning subject to detailed analysis. Likely technological activities are indicated in table 6 . While regional planning has to be in terms of the river basins, we have developed a coarse spatial-temporal matrix for developing a technological matrix as a first step for systems analysis. The country is divided into five regions. The time is divided into three units, short run, medium run and long run. Each technology is envisaged to be started at the optimal time so that each phase is optimally completed.

According to the Sixth Plan complete utilization is scheduled in over 20 years. In our judgement, technological, organisational and institutional capabilities do not warrant such a schedule, but with the utmost efforts for modernization on these fronts, a schedule of 30 years is feasible. However, if the present approach continues water resources cannot be developed even over a much longer period and then too the development will be suboptimal.

The policy on which the recommendation of table 6 is based is that (i) a tempo for completing development over this period is built up and (ii) schemes are taken up on priority which have comparatively higher attractive marginal productivity. It hardly need be stated that table 6 is a tentative policy approach and an integrated regional and temporal trajectory of development has to be worked out as shown in figure 11 with regional focus in the Ganga Basin for illustration.

\section{Planning approach}

It is not as yet adequately appreciated in the engineering profession that water resources development is not a mere technological problem, but is integrally related to total socio-economic-technological developmental planning. Accordingly in the systems planning approach, for convenience, the issues may be grouped under three interacting heads (i) analysis of the physical phenomenon, (ii) socio-economic evaluation criteria, and (iii) systems planning. A typical set of issues and models required to develop water resources at a regional level is shown in table 7. Planning studies and 


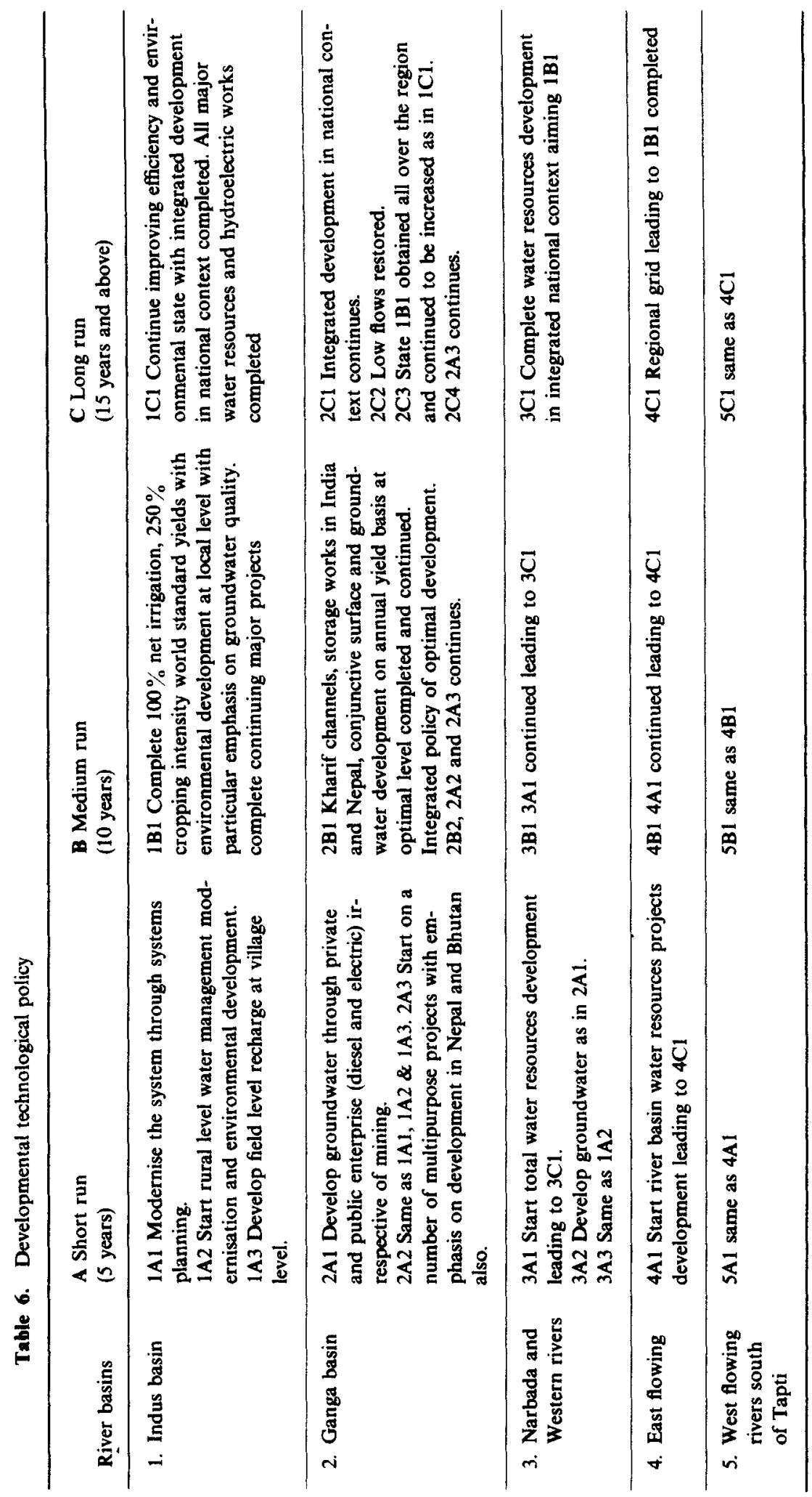




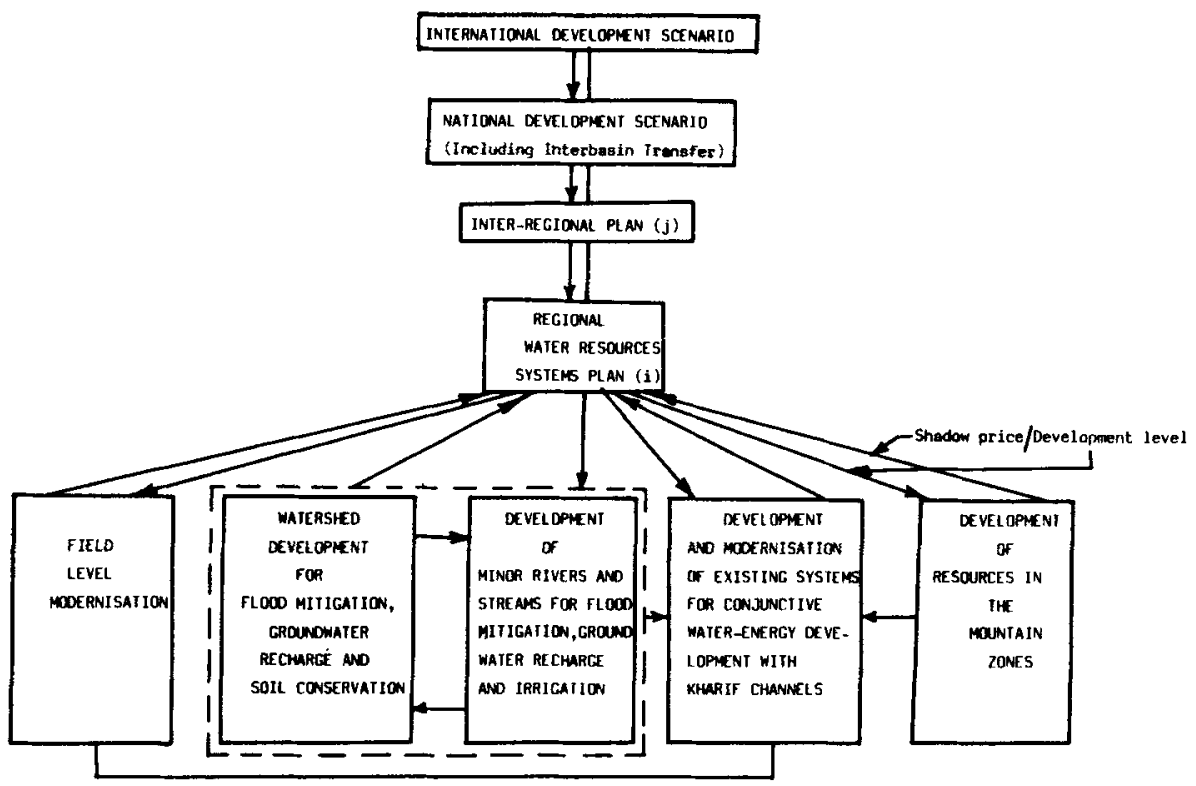

Figure 11. Technological set of options and hierarchy of planning (with focus on the Ganga basin)

Table 7. Relevant issues and models

Socio-economic studies

General and related
sector planning
studies

1. Development strategies

2. Social evaluation of key resources

3. Resources availabilities

4. Evaluation of loss function and risk criteria

5. Project selection criteria
Water and applied resources studies

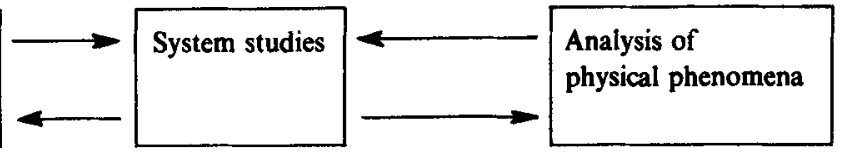

1. Regional optimal allocation of water resources

1. Description of physical phenomena

2. Optimal development constrained by economic and physical resources

2. Analysis and simulation of physical phenomena

3. Project evaluation and selection

\section{Issues}

Models

1. Intersectoral resource allocation model

2. Population studies

3. Food demand models

4. Agricultural sectoral model

5. Technology-efficiency-equity models
1. Preliminary system formulation model

2. System analysis-deterministic model

3. System analysis-stochastic model

4. System simulation models

5. Simulation of crop activities

6. Power sector models

7. Space structuring models

8. System environmental models
1. Hydrologic models

2. Hydrogeological exploration models

3. Surface-ground water simulation model

4. Ground water recharge model

5. Crop-water fertilizer response models

6. Water quality models 
their progression are shown in figure 12 . We start with (i) regional water availability, (ii) water demand, and develop (iii) technological solutions. Each of these three is progressively refined. Reference may be made to the set of case studies to appreciate the details of the aforesaid component studies (Chaturvedi \& Rogers 1985) and to standard texts for the approaches to carry out the study. Systems planning of the water resources of Uttar Pradesh is currently being carried out on these lines and the set of component studies shown in figure 13, gives an idea of the approach (Chaturvedi 1981b).

Regional planning is interrelated to national'policy planning at one end and project planning at the other as shown in figure 14 . We shall briefly discuss the planning at two levels, as related to integrated rural development and in the context of national planning.

As we have emphasized water resources development or any technological activity should be subordinated to socio-economic environmental development. The starting issue is what the rural needs are and how the set of technological activities can be planned so as to generate employment through agriculture and allied activities. For example, as discussed earlier, diesel-operated tubewells were considered to be the first choice in the Ganga basin with other sets of technologies on a bigger scale supplementing it. Activity can be developed at village, block, and district level for the related technological activities. Thus, teams can be developed for manufacturing screens (ferrous or plastic) at block or district level. Industries can be developed for manufacture of pumps and motors at suitable levels from demand and corresponding

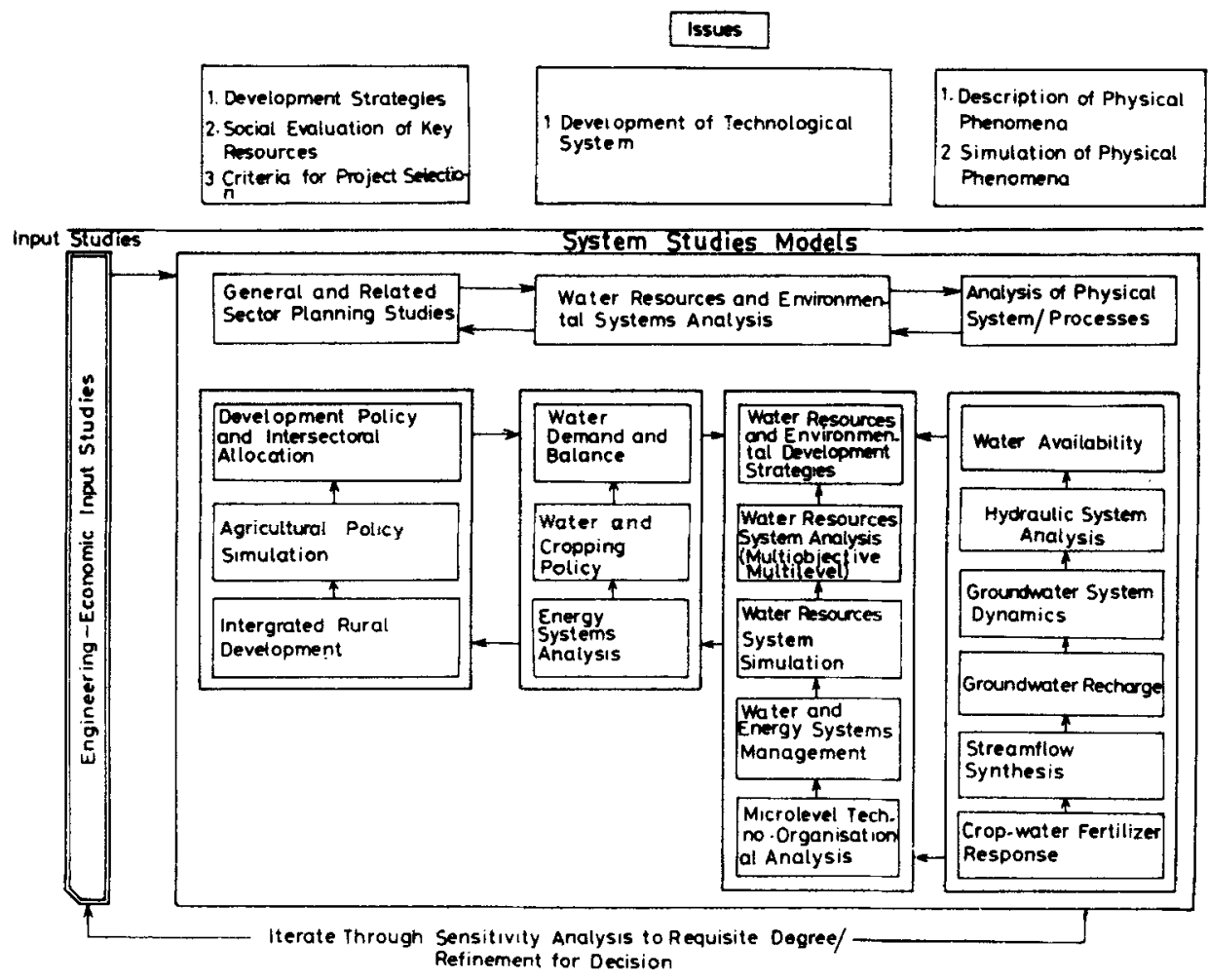

Figure 12. Issues and systems analysis modelling morphology 


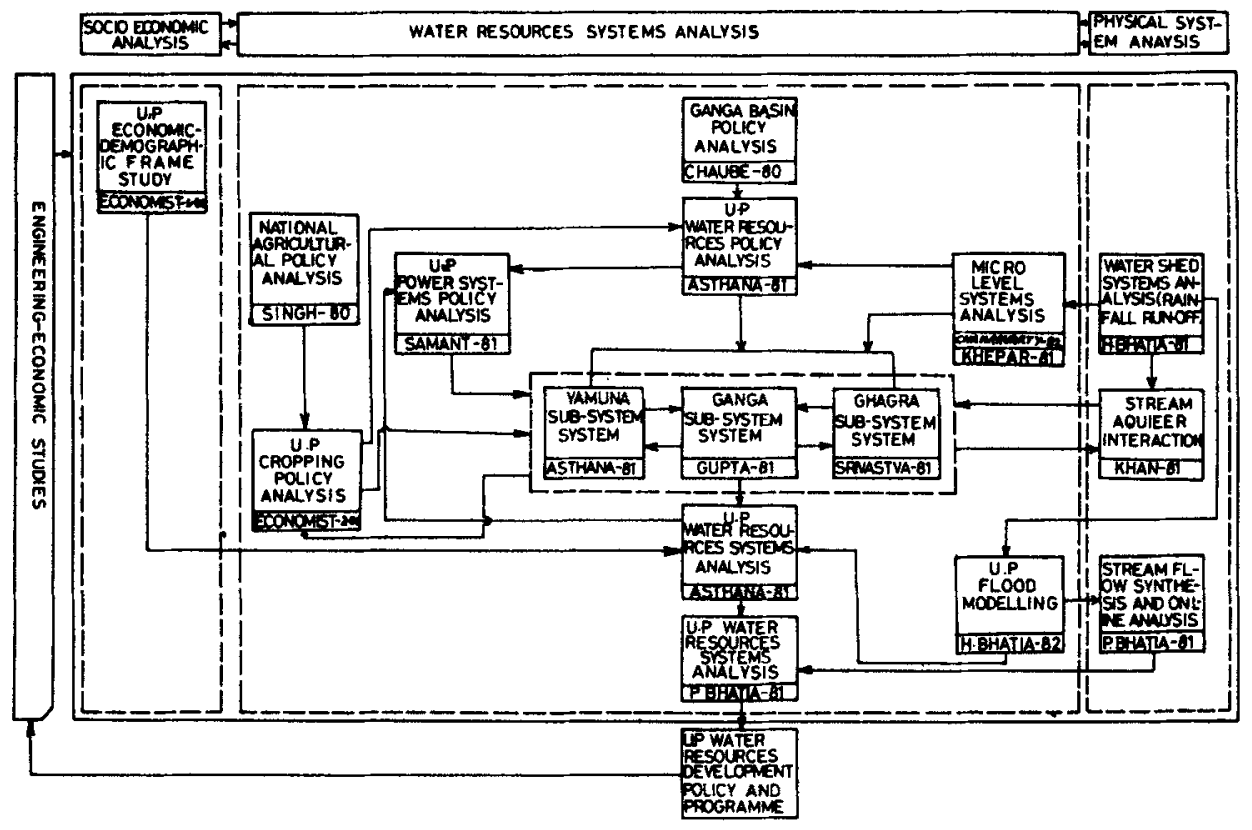

Figure 13. Water resources systems development planning scheme

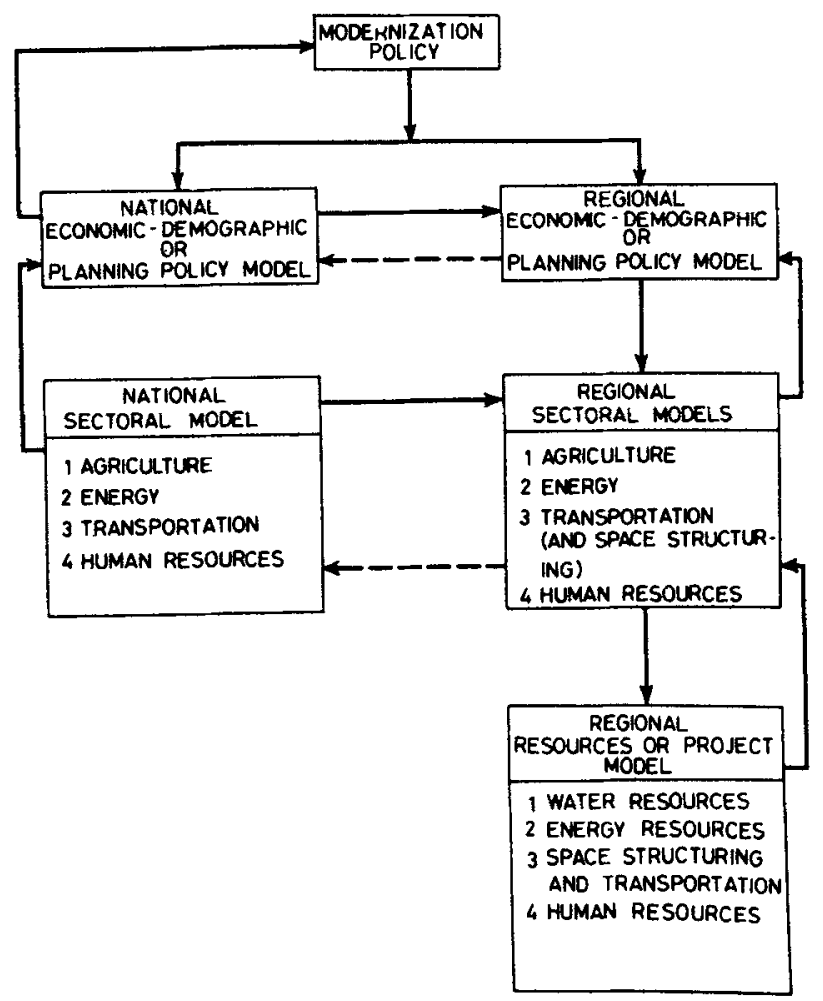

Figure 14. Regional systems analysis modelling morphology 
economies of scale of supply. The central issue is to develop employment, technological culture and resources for appropriate development in which the local people are committed and take the lead in active development.

Development of water resources on such a large scale has national and international interlinkage. With the development at the proposed scale, partial equilibrium analysis is no longer valid and general equilibrium analysis is called for. The detailed approach developed for market economies may not be applicable, and therefore, a more heuristic multilevel analysis to study the interaction at national, regional and farm level has to be developed. At the national level, the policy objective may be said to be to develop irrigation in different regions consistent with balanced regional growth and selfsufficiency (in view of non-market economy and transportation problems), the multiobjective of optimal productions of the major crops, optimal employment generation and optimal nutrient production is obtained at minimum costs and with optimal environmental enhancement. Taking into account regional agro-climatic and technohydrological environmental attributes and budgetary allocations, the trajectory of water resources developmental policy can be worked out. The trade-off between the three objectives or more as may be visualised can be studied. At the regional level, the objective is that, given the cropping pattern and targets, what the options and scheduling policy of the projects should be. At the farmers' level, the objective is that given the projects and corresponding potential of pattern and quantities of water, what the optimum cropping pattern from considerations of financial returns is. An iterative solution satisfying the three-level decision follows (Chaturvedi \& Duggal 1978). As another example of the implication of national interlinkage in view of the changing cropping pattern as development of water resources in different parts of the country takes place, reference may be made to the work of Singh (1980). Optimal water development was studied for nine policy options for the country, divided into 20 river basins.

For the above it may be concluded that there are three factors which lead to the necessity of a long-term national policy planning for water development. One is the circular causatory interlinkage of demand and supply through the technological activity. Second is the possibility of interbasin water transfer and correspondingly optimal interrelated development at the regional and national level. And, the third is the interlinkage due to the development taking place over a period of time. National policy analysis is important not only to determine balanced growth, but even to determine optimum individual project timing, capacity and technological design in view of varying project characteristics and possibility of integrated water transfer viewed as resource and energy. It is considered that most of the projects currently planned or under execution and the management of existing projects is inefficient, and the proposed systems studies at national, regional and village levels should be carried out immediately so that currently proposed developments do not irreversibly and inefficiently commit the valuable natural resources. It could be possible that the technological options are provided with sufficient flexibility for possibility of increasing the capacity, optimally, over a period of time. For instance, the capacity of the series of storage dams due to be constructed over the Narbada or run-of-river hydroelectric development in the Himalayas must be decided from the consideration of the feasibility of the National Water Programme at the appropriate time.

It is important to emphasize that in water resources development, as in all activities, it is not only the end product or the decision that is important, but more so the process of 
decision making that is to be emphasised. Technology is a creative art and science and not merely a routine activity as it often becomes.

\section{Institutional and technological modernization}

Models are an important part of systems analysis. They are valuable as they enable us to perform so to say, "thought experiments". But they do not replace judgement and creativity as real-life issues are much too complicated. They complement judgement by allowing analysis and creativity over a much wider range. It would be clear from the above that water resources development for the new India can no longer be on the currently adopted ad hoc project-by-project basis on outdated colonial policy concepts and technological perceptions, but will have to be on a scientific and long-term basis with concern for the people and the environment. The first pre-requisite for the new approach is Institutional and Educational modernization of the profession. Governmental agencies have to get rid of the bureaucratic-colonial heritage and have to reorient themselves as agents of modernization. The engineers have to be educated to develop proper concepts, attitudes and skills. They have to become specialists and engineers rather than officers. This modernization is required in all phases of technological activity-planning, design, construction, management and research.

We do not elaborate on the institutional change and technological modernization for the new task except to underline that it is most urgent and it involves a complete conceptual and organizational modernization. An integral issue is a colossal programme of long-term continuing education. It is a sad fact that least capability in terms of higher education and research has taken place in water resources sector. The educational programmes must be developed in collaboration with the major educational institutions of the country for this task. These should be specifically designed in collaboration with professional bodies for continuous updating at all levels. Furthermore, institutional change and education at the users' level are also important components of the modernization task. Village cooperatives have to be developed and provided with extension services. In short a complete individual and organizational revolution is called for. It is interesting to note that the Sixth Plan has identified these issues as part of the objectives for achieving development.

One issue may be specifically mentioned. The first step in this revolution is intellectual freedom. Even after 30 years of political independence, mental slavery and a sense of inferiority to the West continues in India. Foreign experts are often invited for instant development recipes. Some Indian techno-bureaucrats hanker after foreign trips or instant education courses without ever realising that development must in the last analysis be indigenous. Collaboration is no doubt valuable, but it must be on equal terms and indigenous development is the first pre-requisite for meaningful collaboration. Unless there is intellectual freedom and commitment to the development of the poor, appropriate technological development is a distant goal.

\section{Conclusion}

As stated at the outset, our effort has been to demonstrate that a revolution in concepts and approach, and institutional and technological modernization is needed to meet the 
tremendous challenge of water resources development in India. The first step is a break from the colonial hangover, and attainment of intellectual freedom.

A scientific approach to planning leads to (a) scientific policy and programme at the national level and (b) scientific policy and activities at project level.

A scientific planning approach is indicated. It is necessary to implement it immediately, otherwise the individual projects will be inefficient and wasteful of developmental potential and development would not be attained in due time.

\section{References}

Bhatia B M 1967 Famines in India (Bombay: Asia Publishing House)

Cautley P T 1860 Completion report Ganges Canal (London: Smith, Elder \& Co.)

Chaturvedi M C 1973 Indian National Water Plan and Grid, First World Congress, Int. Water Resources Assn, Chicago

Chaturvedi M C 1976 Water: Second India Studies (New Delhi: Macmillans)

Chaturvedi M C 1979 Integrated water and energy planning with interbasin transfer in Indian Indus basin, XVIII Congress, Int. Assn for Hydraulic Research, Cagliari, Italy

Chaturvedi M C 1981a Ground water development and flood mitigation-systems planning, Indo-US Workshop on Flood Mitigation and Water Resources Dev., Indian Institute of Technology, New Delhi

Chaturvedi M C (ed.) 1981b Water and power systems planning for UP, 1st Annual Report, Indian Institute of Technology, New Delhi

Chaturvedi M C 1984 Systems approach to Water Resources Planning (New Delhi: Tata McGraw Hill)

Chaturvedi M C, Revelle R, Srivastava 1975 Ganga water machine II-Induced groundwater recharge, II World Congress, Int. Water Resources Assn, New Delhi

Chaturvedi M C, Srivastava V K 1979 Water Resources Res. 15: 1156-1166

Chaturvedi M C, Duggal K N 1978 Multilevel-multiobjective systems analysis in agriculture and irrigation, II Int. Symp. on large engineering systems, University of Waterloo, Waterloo, Ontario, Canada

Chaturvedi M C, Khepar S D $1981 \mathrm{~J}$. Water Resources Planning and Management, ASCE (Submitted)

Chaturvedi M C, Rogers P 1985 Sadhana 8: 329-350

Clairmonte F 1961 The economic liberalism and under-development (Bombay: Asia Pub. House)

de Mare L 1977 An assessment of the World Water situation by 2000, Water Int. 2: 7-19

Indo-US Scientists Workshop, Proc. 1981, Flood mitigation and water resources development, Indian Institute of Technology, New Delhi

Irrigation Commission Report, 1972 Volume 1, Government of India, New Delhi

Lahiri A 1975 Commerce Annu. Number 131: 19-27

Lansing J B 1966 Transportation and economic policy (New York: The Free Press)

Leeden F 1975 Water resources of the world (New York: Port Washington)

Lieftink P, Sadove A R, Creyke T 1969 Water and power resources of West Pakistan (Baltimore and London: Johns Hopkins Press)

Murthy Y K 1975 Commerce Annu. Number 131: 9-12.

National Commission on Agriculture 1976 Part V, Government of India, Ministry of Agriculture and Irrigation, New Delhi

National Commission on Floods 1980 Government of India, Ministry of Energy and Irrigation, New Delhi

National Perspectives for Water Resources Development 1980 Government of India, Ministry of Irrigation, New Delhi

Rao K L 1976 India's water wealth (New Delhi: Orient Longmans)

Rao K L 1978 River interlinks for irrigation in India, Hindustan Times, April 8

Revelle R, Herman T 1972 Some possibilities for international development of the Ganga-Brahmaputra basin, Research Report, Harvard University, Centre for Population Studies, Massachusetts, USA

Revelle R, Lakshminarayanan V 1975 Science 188

Singh $\mathbf{R} 1980$ Study of some aspects of water resources and agricultural policy of India, Ph.D. thesis, Indian Institute of Technology. New Delhi

Sixth Five Year Plan (1980-85) 1981 Government of India, New Delhi 
Sohoni V M 1976 Design of low capacity reversible pumps for irrigation, M.Tech. Thesis, Indian Institute of Technology, New Delhi

Swamy S 1973 Economic growth in China and India, 1952-70 (The University of Chicago Press)

Water Resources Development in India, 1977 Indian National Committee for the UN Water Conference, Government of India, New Delhi

World Bank Operations 1972 Sectoral programmes and policies (Baltimore and London: The Johns Hopkins Press) 